Atmos. Chem. Phys. Discuss., 10, 8553-8594, 2010

www.atmos-chem-phys-discuss.net/10/8553/2010/

(C) Author(s) 2010. This work is distributed under

the Creative Commons Attribution 3.0 License.

This discussion paper is/has been under review for the journal Atmospheric Chemistry and Physics (ACP). Please refer to the corresponding final paper in ACP if available.

\title{
Aerosol dynamics in the Copenhagen urban plume during regional transport
}

\author{
F. Wang ${ }^{1,3}$, P. Roldin ${ }^{2}$, A. Massling ${ }^{3}$, A. Kristensson ${ }^{2}$, E. Swietlicki ${ }^{2}$, D. Fang ${ }^{1}$, \\ and M. Ketzel ${ }^{3}$ \\ ${ }^{1}$ Institute of Nuclear and New Energy Technology, Tsinghua University, 100084, Beijing, China \\ ${ }^{2}$ Division of Nuclear Physics, Lund University, 22100, Lund, Sweden \\ ${ }^{3}$ National Environmental Research Institute, Department of Atmospheric Environment, \\ Aarhus University, Denmark
}

Received: 27 March 2010 - Accepted: 29 March 2010 - Published: 1 April 2010

Correspondence to: M. Ketzel (mke@dmu.dk)

Published by Copernicus Publications on behalf of the European Geosciences Union.

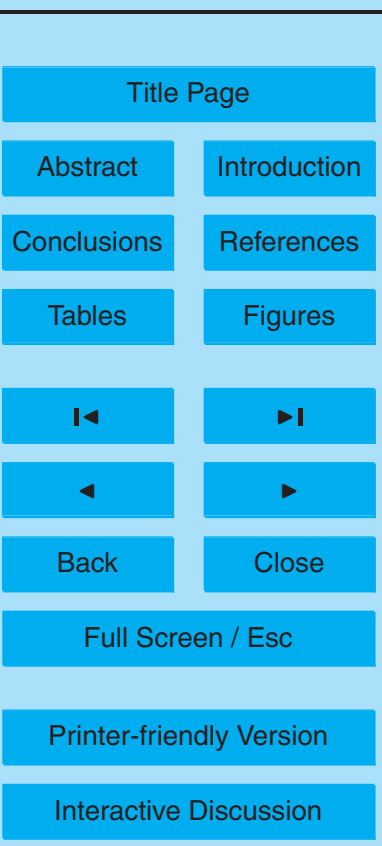

Printer-friendly Version

Interactive Discussion

Aerosol dynamics in the Copenhagen urban plume

F. Wang et al.

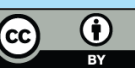




\section{Abstract}

Aerosol particles in the submicrometer size range $\left(\mathrm{PM}_{1}\right)$ have serious impacts on human health and climate. This work aims at studying the processes relevant for physical particle properties in and downwind Copenhagen and evaluating the capability of a de5 tailed aerosol dynamics and chemistry model (ADCHEM) to describe the submicrometer aerosol dynamics in a complex urbanized region, subjected to a variety of important anthropogenic sources. The study area is the Oresund Region with Copenhagen (about 1.8 million people) as the major city, including the strait separating Denmark and Sweden with intense ship traffic. Modeled aerosol particle number size distributwo stations in the Copenhagen area in Denmark and one station in southern Sweden.

The measured and modeled increments in $\mathrm{NO}_{\mathrm{x}}$ concentrations from rural background to the urban area showed satisfactory agreement, indicating that the estimated $\mathrm{NO}_{\mathrm{x}}$ emissions and modeled atmospheric dispersion are reasonable. For three out of

15 five case studies, the modeled particle number concentrations and size distributions are in satisfactory agreement with the measurements at all stations along the trajectories. For the remaining cases the model significantly underestimates the particle number concentration over Copenhagen, but reaches acceptable agreement with the measurements at the downwind background station in Sweden. The major causes for this were identified as being the lack of spatial resolution in the meteorological data in describing boundary layer mixing heights and the uncertainty in the exact air mass trajectory path over Copenhagen. In addition, particle emission factors may also have been too low. It was shown that aerosol dynamics play a minor role from upwind to urban background, but are important 1-2 $\mathrm{h}$ downwind the city. Real-world size-resolved

\section{Aerosol dynamics in the Copenhagen urban plume}

F. Wang et al.

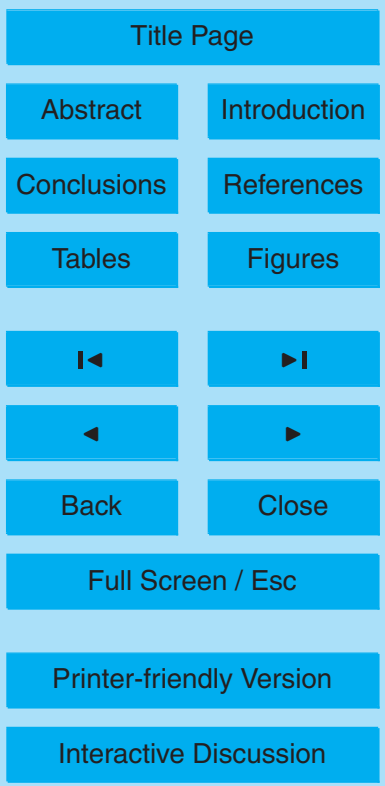




\section{Introduction}

Airborne aerosol particles influence the radiative budget of the earth by direct and indirect processes (IPCC, 2007). In addition, they cause visibility degradation (Malm, 2003) and have detrimental effects on human health (Pope and Dockery, 2006).

5 A representation or surrogate of the size dependent chemical composition of fine $(<2.5 \mu \mathrm{m}$ in diameter) or sub-micrometer $(<1 \mu \mathrm{m}$ in diameter) particles is required in place of $\mathrm{PM}_{2.5}$ and $\mathrm{PM}_{10}$ to correctly understand and quantify climate effects on the regional and global scale (Spracklen et al., 2006; Su et al, 2006). In particular, we recognize that chemical and size resolved data is needed to be able to quantify the source emissions and the transformation that particles undergo during long range transport from their emissions all the way to an arbitrary receptor point. Additionally, $\mathrm{PM}_{2.5}$ and $\mathrm{PM}_{10}$ are not suitable tools during the specific occasions as health effects correlate better with the submicrometer number concentration than the mass concentration (Weichenthal et al., 2007; Su et al., 2006; Zhang et al., 2005). The pursue for the particle 15 number size distribution and chemical composition is further necessary to be able to calculate the size-segregated deposition of particles in the human airways (Löndahl et al., 2009).

In this study we mainly focus on emissions from urban traffic. Extensive particle number size distribution measurements have already been performed in many urban areas (review by Morawska et al., 2008), and vehicular emission factors have been determined, too (Imhof et al., 2005; Kittelson et al., 2004; Beddows and Harrison, 2008). Considerable interest has recently been redirected towards the understanding of the evolution of number concentration, size, and composition of aerosol particles after their first release in the atmosphere and main findings are briefly summarized in the following. Complex and rapid aerosol dynamics including nucleation, coagulation, condensation and dilution determine the evolution of a particle population in the first seconds after emission from the tailpipe into the atmosphere (see e.g. Kittelson et al., 2006; Uhrner et al., 2007).

10, 8553-8594, 2010

\section{Aerosol dynamics in the Copenhagen urban plume}

F. Wang et al.

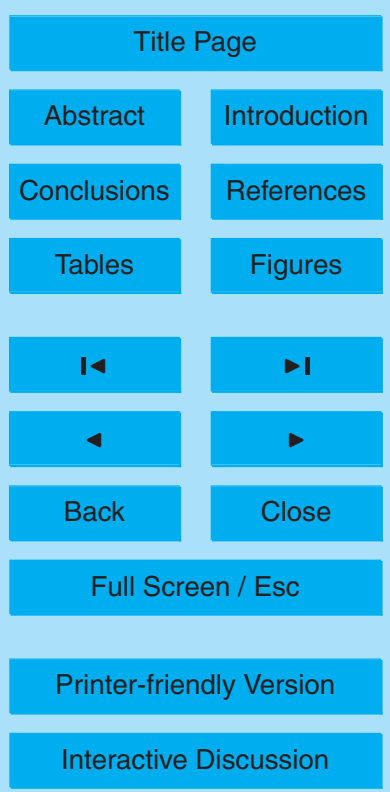

Interactive Discussion 
The processes slow down and the emitted aerosol plume ages within a minute or a few minutes after the emissions or in other words within between $10 \mathrm{~m}$ and $1 \mathrm{~km}$ distance from the tailpipe. There are at least five studies that have estimated relevant aerosol dynamic processes downwind of major urban roads, highways or freeways us5 ing different approaches. For these relatively well ventilated roads dilution tends to be the dominating aerosol process (Zhu et al., 2002; Ketzel and Berkowicz, 2004a; Zhang et al., 2004; Pohjola et al., 2007). Additionally condensation/evaporation was also found significant for nucleation mode particles $<50 \mathrm{~nm}$ in diameter (Zhang et al., 2004; Pohjola et al., 2007) and condensation and coagulation seems to play an important 10 part depending on the external conditions. In relatively more confined compartments where mixing with background air is limited such as at urban intersections or kerbsides, self-coagulation (Jacobson and Seinfeld, 2004) and deposition (Ketzel and Berkowicz, 2004a) are probably important besides dilution. In tunnels, where number concentrations are even higher and the surrounding walls are close to the emissions, coagulation 15 and deposition are dominating and dilution is recognized to have small importance only (Gidhagen et al., 2003; Ketzel and Berkowicz, 2004a).

The plume ageing continues on the urban or near-regional scale within hours after the first emission, i.e. a few kilometers to a few tens of kilometers downwind. Judging by the time-scale analysis by Ketzel and Berkowicz (2004a), the three processes deposition, condensation/evaporation and inter-modal coagulation could potentially be important to transform particles between the kerbside to the urban background, where both the results of Gidhagen et al. (2004) and Ketzel and Berkowicz (2005) show that about $25 \%$ of the particles are lost. Here, the similarities end and different authors attribute street to urban background transformation to mainly inter-modal coagulation, condensation and coagulation, coagulation and deposition or to all three processes (Jacobsen and Seinfeld, 2004; Wehner et al., 2002; Zhang and Wexler, 2002; Gidhagen et al., 2004; Ketzel and Berkowicz, 2005). In fact, Wehner et al. (2002) and Ketzel and Berkowicz (2005) show that different combinations of condensation, coagulation or deposition can be used to correctly simulate measured size distributions. A review

\section{Aerosol dynamics in the Copenhagen urban plume}

F. Wang et al.

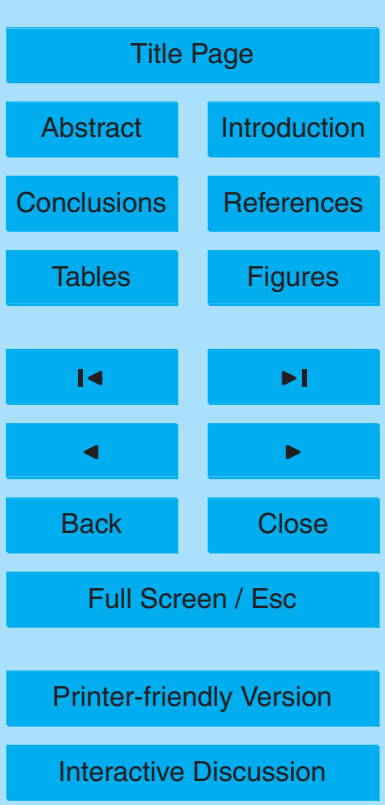


of the literature clearly states that more research is needed to be able to know how urban plumes are transformed from street to urban background level where particles significantly contribute to air pollution exposure levels.

Roldin et al. (2010a) have developed the trajectory model ADCHEM (Aerosol Dy5 namic and CHEmistry Model) to study the transformation of the particle number size distribution from the local scale to the regional scale as potential input for global chemistry and transport models (CTMs). ADCHEM is a Lagrangian model following the motion of infinitesimal material fluid elements, which by definition move with the local instantaneous flow (Yeung, 2002). Successful modeling of the dynamics, the disper10 sion and the mixing processes for both continental and marine boundary layers are documented in the literature (Weil et al., 2004; Brickman and Smith, 2002; Mueller and Veron, 2009). The ADCHEM model has been validated and applied to simulate the ageing of the urban plume from the city of Malmö with 280000 inhabitants in southern Sweden (Roldin et al., 2010b). It was found that the Malmö contribution $50 \mathrm{~km}$ down15 wind of the city centre is highest for particles between $40 \mathrm{~nm}$ and $100 \mathrm{~nm}$ in diameter and that coagulation and dry deposition are dominating during the ageing.

This study investigates the relevant physical processes of particles in and downwind Copenhagen and at evaluates the capability of ADCHEM to reproduce the measured submicrometer particle number size distributions in a complex urbanized region, sub20 jected to a variety of important anthropogenic sources including road and ship traffic. For these purposes the ADCHEM model has been extended by implementation of an emission inventory with respect to primary particle emissions from Copenhagen city, especially vehicular particle number emissions. Using the extended model we predict the particle number size distribution in urban background Copenhagen. Recommendations are provided on the importance of different aerosol dynamic processes during urban plume ageing on the different time scales. The model was initialised with measured data at a rural site upwind of Copenhagen and compared with measurements at an urban background site in Copenhagen, and at a regional background site downwind of Copenhagen, where urban contribution was found to be significant from measure-

\section{Aerosol dynamics in the Copenhagen urban plume}

F. Wang et al.

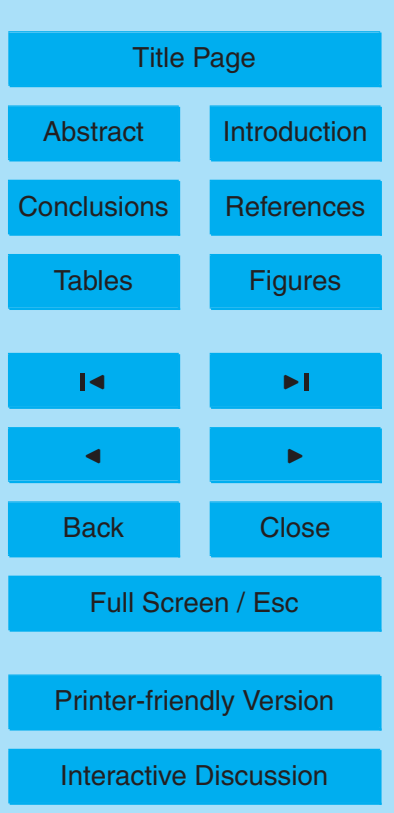

Interactive Discussion 
ments in a previous study (Ketzel et al., 2004). We finally estimated primary particle emissions from road and ship traffic and woodstoves in terms of chemically composed submicrometer particle number size distributions and used the model application to verify the particle number traffic emission profile obtained from our previous study in 5 the Copenhagen area (Wang et al., 2010).

\section{Experimental studies}

\subsection{Measurement sites and instrumentation}

The location of the three measurement sites used for a validation of model results in this study is given in Fig. 1. Two stations belong to the Danish Air Quality Monitoring Programme (Kemp et al., 2008), the urban background station at the roof of $\mathrm{H}$. C. Ørsted Institute in Copenhagen (HCOE; $\left.12^{\circ} 33^{\prime} 42^{\prime \prime} \mathrm{E}, 55^{\circ} 42^{\prime} 2^{\prime \prime} \mathrm{N}\right) 20 \mathrm{~m}$ above ground level and the background station at Lille Valby (LVBY; $12^{\circ} 7^{\prime} 34^{\prime \prime} \mathrm{E}, 55^{\circ} 41^{\prime} 14^{\prime \prime} \mathrm{N}$ ) ca. $30 \mathrm{~km}$ west of Copenhagen. Lille Valby can be characterized as a near-city background due to the influence of the greater Copenhagen area in the east and the town of Roskilde in the south. The third background station, Vavihill (VVHL; $13^{\circ} 09^{\prime} \mathrm{E}, 56^{\circ} 01^{\prime} \mathrm{N}$ ), is located in Sweden ca. $60 \mathrm{~km}$ north-east of Copenhagen, Denmark, and ca. $50 \mathrm{~km}$ north of Malmö, Sweden, and is operated by Lund University, Sweden. The Vavihill site is located in the middle of a forest area (Söderåsen), and is part of the EMEP (emep.int) and EUSAAR (eusaar.net) networks. The site can be considered as a regional background site.

At all sites, Differential Mobility Particle Sizers (DMPS) were used to measure the particle number size distribution. The DMPS at the Danish sites (LVBY and HCOE) covered the particle diameter range from $5.6 \mathrm{~nm}$ to $700 \mathrm{~nm}$ (Ketzel et al., 2004b) with a time resolution of $3 \mathrm{~min}$. At Vavihill (VVHL) the DMPS covered the size range from 3 to $900 \mathrm{~nm}$ diameter with a time resolution of $10 \mathrm{~min}$ (Kristensson et al., 2008).

25 Gas phase pollutants $\mathrm{NO}_{\mathrm{x}}\left(\mathrm{NO}, \mathrm{NO}_{2}\right)$ and $\mathrm{O}_{3}$ were also measured at HCOE and LVBY with API NO $\left(\right.$ model 200A) and with $\mathrm{APIO}_{3}$ analyzers (model 300A) respectively.

Aerosol dynamics in the Copenhagen urban plume

F. Wang et al.

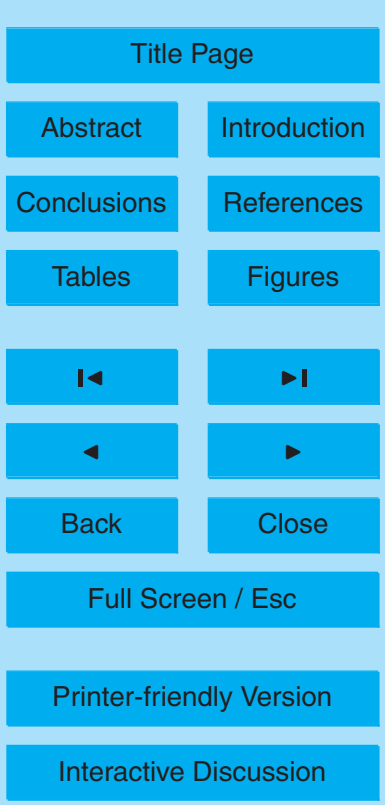


There is a sub-set of 6 weeks of data available during 2005 (from May to October), when particle size measurements from all three sites were of good quality. For the case studies presented in this paper a small part of this sub-set is selected during time periods of suitable wind directions.

\section{2.2 Meteorological conditions and total particle number concentrations}

The HCOE roof site was equipped with a meteorological station located at $10 \mathrm{~m}$ height above roof level measuring the following parameters: wind direction (WD), wind speed (WS), relative humidity $(\mathrm{RH})$, temperature $(T)$, and global radiation. The wind rose in Fig. 2 shows the wind distribution during the whole year of 2005 and the 6-week subset 10 period during 2005. Westerly winds were predominant for both data sets. We selected 2 occasions with westerly winds in the sector $250^{\circ}-290^{\circ}$ for the model simulation cases in group $A$ and 3 occasions with south-westerly winds in the sector $200^{\circ}-250^{\circ}$ for the model simulation cases in group B (Fig. 1). The simulations are described in more detail in Sect. 3.3.

15 The observed average total particle number (PN) concentrations during the 6week measurement period were 4530 particles $\mathrm{cm}^{-3}, 6050$ particle $\mathrm{cm}^{-3}$ and 3840 particles $\mathrm{cm}^{-3}$ at the LVBY, HCOE, and VVHL stations, respectively. The observed particle number size distributions (PNSDs) are shown in Fig. 3 for the sub-set period and for the wind sector $200^{\circ}-250^{\circ}$ when the wind was blowing from the area south of LVBY to HCOE (central Copenhagen) and reaching the area of VVHL. Although the air mass did not pass directly over LVBY for this wind sector, the upwind Copenhagen conditions south of LVBY are assumed to be well approximated by the LVBY station.

The average PNSDs during the sub-set period showed a dominating Aitken mode between $40 \mathrm{~nm}$ and $80 \mathrm{~nm}$ diameter at all stations, where the concentration was highest at HCOE and lowest at VVHL. Within the selected wind sector (see Fig. 3b), the size distribution at VVHL contained 2 nucleation modes at $15 \mathrm{~nm}$ and $25 \mathrm{~nm}$ diameter respectively, which did not appear at LVBY. This phenomenon might be due to the emis-

Aerosol dynamics in the Copenhagen urban plume

F. Wang et al.

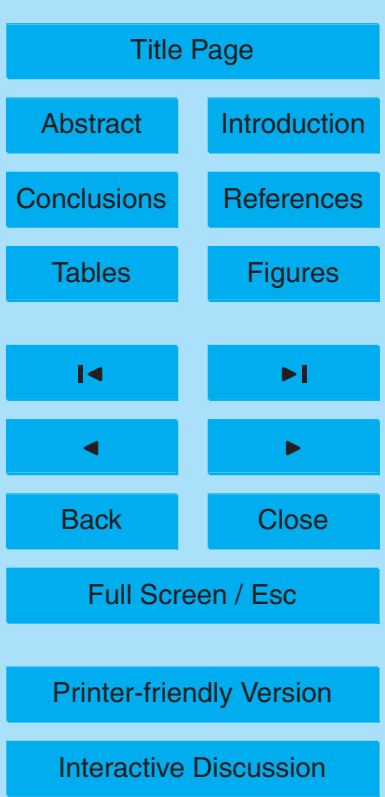


sions of precursors in Copenhagen urban area that contributed to particle formation in southern Sweden.

\section{Modeling methods}

\subsection{Model description}

5 A trajectory model for aerosol dynamics, gas phase chemistry and radiative transfer simulations (ADCHEM) has been applied in this study (Roldin et al., 2010a). The model solves the atmospheric diffusion equation in one or two space dimensions along an air mass trajectory, including atmospheric aerosol dynamic processes, particle and gas phase chemistry and a radiative transfer model.

10 The aerosol dynamic model in ADCHEM is a sectional model which divides the particle number size distribution into finite size bins. Here we use 54 bins in the size range from $2 \mathrm{~nm}$ to $2500 \mathrm{~nm}$. The particles are assumed to be internally mixed which means that particles of the same size have the same composition. The model includes Brownian coagulation, dry deposition, wet deposition, in cloud processing, condensation, evaporation, primary particle emissions, homogeneous nucleation and dispersion in the vertical (1-D model) and horizontal direction (2-D model).

The model treats both organic and inorganic particle chemistry with sulfate, nitrate, ammonium, sodium, chloride, non water soluble minerals (metal oxides/hydroxides), Elemental Carbon (EC), Primary Organic Aerosol (POA), Anthropogenic and Biogenic Secondary Organic Aerosol (ASOA and BSOA respectively), and in cloud processing of the aerosol particles, including dissolution of sulfur dioxide and hydrogen peroxide into the particle water phase. ASOA and BSOA are in general formed by condensation of oxidation products of $\alpha$-pinene, $\beta$-pinene, $\Delta 3$-carene, D-limonene, isoprene, benzene, toluene and xylenes. The aerosol dynamics and particle chemistry model is coupled to the gas phase chemistry model through the condensation and evaporation processes.

The gas phase chemistry model calculates the gas phase concentrations of 63 dif-

Aerosol dynamics in the Copenhagen urban plume

F. Wang et al.

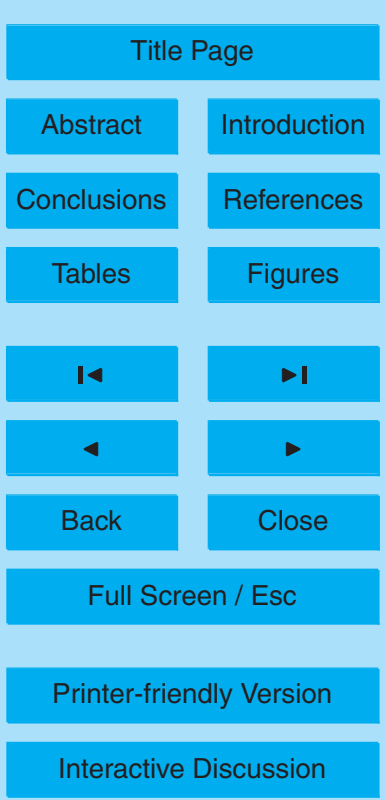

Interactive Discussion 
ferent species, using 119 different chemical reactions. The actinic flux, which used to calculate the photochemical reaction rates, is derived with the radiative transfer model. The readers can refer to Roldin et al. (2010a) for a more detailed description of ADCHEM.

5 For most of the simulations performed in this study the 1-D version of ADCHEM was used, employing 20 vertical grid cells. For one of the simulated case studies the 2-D version was also applied, using 20 vertical and 20 horizontal grid cells. The vertical and horizontal grid resolution was $100 \mathrm{~m}$ and $1000 \mathrm{~m}$, respectively.

The model solves all aerosol dynamic equations with a time interval of $15 \mathrm{~s}$, except 10 the condensation/evaporation equation, which is solved for every $5 \mathrm{~s}$. Wet deposition was not included, as only cases with sunny weather were chosen. Days with new particle formation observed between the stations LVBY, HCOE, and VVHL were not chosen either.

\subsection{Primary particle number emission profiles}

15 In the study area we identified that road traffic, wood stove combustion and ship transport were the main sources of particulate emissions in the submicrometer size range. Furthermore, the profiles of the particle number size distribution for these three sources were derived from the literature and they are shown in Table 1 and Fig. 4. The size distribution profile of the particle number emissions from road traffic was based on our previous study in the Copenhagen urban area obtained under real world conditions (Wang et al., 2009). Particle number emissions were scaled to $\mathrm{NO}_{\mathrm{x}}$ emissions with a ratio of $\mathrm{PN}$ to $\mathrm{NO}_{\mathrm{x}}$ equaling to $2 \times 10^{14}$ particles $\left(\mathrm{gNO}_{\mathrm{x}}\right)^{-1}$. A recently undertaken Danish research project on wood stoves determined the particle number size distribution profile in terms of emissions, which was scaled to $\mathrm{PM}_{2.5}$ emission from the same 25 source with a ratio of $\mathrm{PN}$ to $\mathrm{PM}_{2.5}$ equal to $5 \times 10^{14}$ particles $\left(\mathrm{g} \mathrm{PM}_{2.5}\right)^{-1}$ (Wåhlin et al., 2010). The particle number size distribution profile from ship traffic was based on the study by Petzold et al. (2008) in the English Channel. We scaled it to $\mathrm{PM}_{2.5}$ as well

Aerosol dynamics in the Copenhagen urban plume

F. Wang et al.

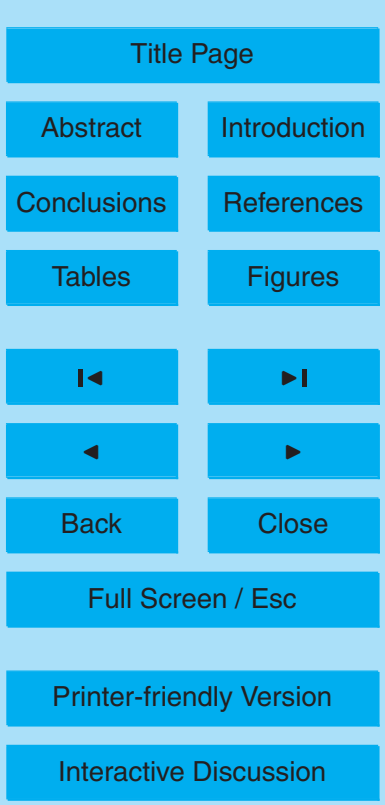


with a ratio of $\mathrm{PN}$ to $\mathrm{PM}_{2.5}$ equal to $1.1 \times 10^{15}$ particles $\left(\mathrm{gPM}_{2.5}\right)^{-1}$ by assuming a mean particle density of $1000 \mathrm{~kg} \mathrm{~m}^{-3}$.

In our model simulations, the inventory of the anthropogenic particulate emission factors was put together by three emission inventories with different resolutions for the 5 different sources. For the road sources in the Copenhagen region a $\mathrm{NO}_{x}$ emission inventory with a spatial resolution of $1 \times 1 \mathrm{~km}^{2}$ was used based on NERI's traffic database with traffic volumes on all road links in Denmark for the year 2005 together with emission factors from the latest version of the COPERT IV model applied for 2008 conditions. For other (non-road) sources and other areas in Denmark, an emission inventory 10 with $17 \times 17 \mathrm{~km}^{2}$ spatial resolution was used based on Danish national emission inventories for the year 2007 made by NERI (emission.dmu.dk). For other European areas the European Monitoring and Evaluation Programme (EMEP) emission inventory with $50 \times 50 \mathrm{~km}^{2}$ spatial resolution was used (emep.int). For southern Sweden an emission inventory for road transportation sources as well as for ship emissions with a spatial 15 resolution of $1 \times 1 \mathrm{~km}^{2}$ was used, from the work by Gustafsson et al. (2007). The EMEP emissions were derived from EMEPs emission database for the year 2006 (Vestreng et al., 2006). All emission inventories included the same categories of emission sources as given in the EMEP database. Country specific forest and meadow/pasture area coverage data from Simpson et al. (1999) and emissions of NMVOCs (non-methane VOCs), $\mathrm{NO}_{\mathrm{x}}, \mathrm{SO}_{2}, \mathrm{CO}, \mathrm{NH}_{3}$ and $\mathrm{PM}_{2.5}$ were fitted along the trajectories used for the simulations. The forest and meadow/pasture data was used to calculate the biogenic monoterpene and isoprene emissions and estimate the surface albedo and surface roughness length along the trajectories. The forest species distribution from Simpson et al. (1999) were used together with species specific biomass density, leaf area index and emission potential from the study of Steinbrecher et al. (2009) to estimate the emissions of isoprene, $\alpha$-pinene, $\beta$-pinene, $\Delta 3$-carene and D-limonene, using the light and temperature dependence according to Guenther (1997).

The average anthropogenic emissions in the different categories are subjected to typical seasonal, weekly and daily variations based on EMEP's data. In addition, sea

\section{Aerosol dynamics in the Copenhagen urban plume}

F. Wang et al.

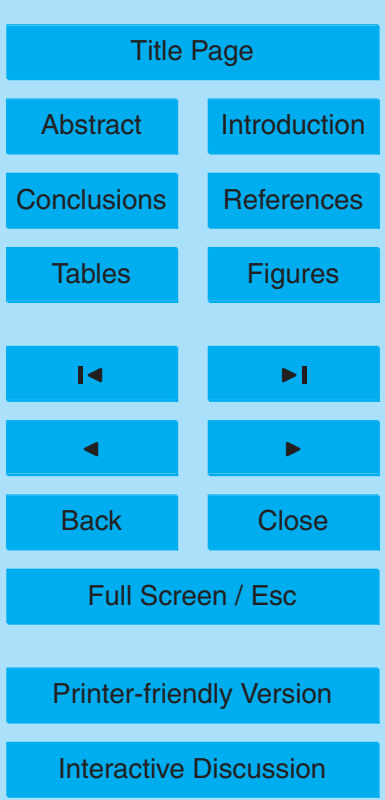


salt emissions were included according to the study of Mårtensson et al. (2003).

\subsection{Meteorological input and model initial}

The meteorological data used in the model were downloaded from NOAA Air Resource Laboratory (ARL) Real-time Environmental Application and Display system (READY) 5 (Rolph, 2003). ARL's READY provides the HYbrid Single-Particle Lagrangian Integrated Trajectory (HYSPLIT) model which can be used interactively and provides forward and backward air mass trajectories from a source point within a desired time period. In addition, the relevant meteorological parameters along the trajectory including WS, WD, $\mathrm{RH}$, mixing height, rain, and global radiation were obtained. Along each

10 trajectory, one hour resolution data of solar irradiance, mixing height and rain fall intensity was extracted. For every three hours along the trajectories, vertical profiles of temperature, wind speed and relative humidity were downloaded. These data were linearly interpolated both spatially to the fixed vertical grid and used as input for the simulations as well as in time to increase the temporal resolution to $15 \mathrm{~s}$, which was 15 the time step used in the model.

Two groups of trajectories were selected (Fig. 1) for simulations according to different wind directions and different pathways of the trajectories. On the 6 June, 2005, the wind direction was constant from west to east and the trajectories passed over the area of LVBY and arrived at HCOE without passing through VVHL afterwards. This 20 group of trajectories is labeled as group A. On the 3 June, 2005, the wind direction was from south west to north east and the trajectories passed over the rural area in the south west of Copenhagen (LVBY as representative) to HCOE and passed further the Oresund Strait and over regional background area in southern Sweden (VVHL as representative). This group of trajectories connecting all three stations is labeled as 25 group B.

Backward trajectories were calculated for $48 \mathrm{~h}$ and forward trajectories for $24 \mathrm{~h}$ all starting at the HCOE location. Particle number size distributions were kept constant in the model until the calculated air masses arrive at LVBY (or the equivalent longitude).

\section{Aerosol dynamics in the Copenhagen urban plume}

F. Wang et al.

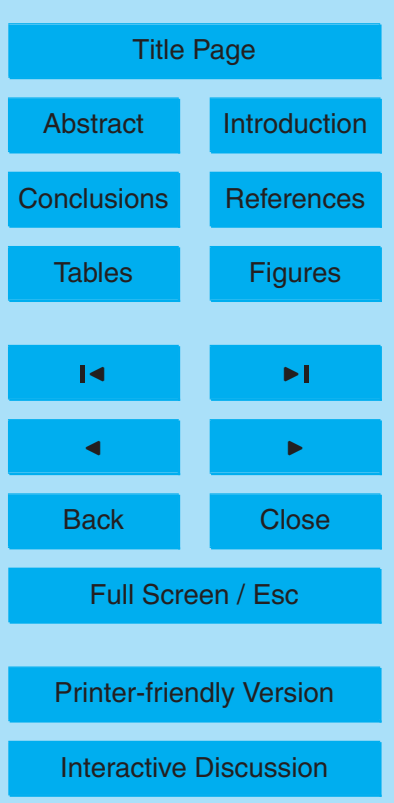


The travel time from LVBY to HCOE is about $1 \mathrm{~h}$ for group A cases and about $1.5 \mathrm{~h}$ for group B cases.

Before LVBY, the chemical composition of the particles and the gas phase concentrations were initialized from the model simulations. The initial gas concentrations which 5 vary according to season, altitude and latitude were taken from Simpson et al. (2003).

Cloud processes and wet deposition were turned off in our study, as no-rain and sunny days were chosen for the simulations. The measured particle number size distribution data at LVBY were used as initial size distribution in the model. Since the measured size distributions had fewer size bins than represented in the model, the 10 measured size distributions were converted, by linear interpolation, to 54 size bins, between $2 \mathrm{~nm}$ and $2500 \mathrm{~nm}$.

\section{Model results}

Each simulation was performed over a total of $72 \mathrm{~h}, 48 \mathrm{~h}$ backward and $24 \mathrm{~h}$ forward trajectories from the HCOE receptor point. In this section the results of $7 \mathrm{~h}$ close HCOE 15 are presented, where the emission inventories has the highest resolution. The predicted values were also compared to the measured data at the three stations. $\mathrm{NO}_{\mathrm{x}}$ concentration was used as a tracer to evaluate the dispersion in the model, which gave credibility to the simulation of the transport and turbulent mixing of the particles.

\subsection{Evaluation of simulations for $\mathrm{NO}_{x}$ and particles: group $\mathrm{A}$}

20 For group A, two cases were selected on the same day, June 6 of 2005, when the wind was relatively stable from west to east. The air mass that arrived at HCOE at 13:00 LT (Local Time) was labeled as A1 and the one arriving at 16:00 LT was labeled as A2. Both air masses passed over the area of LVBY and then one hour later at HCOE. During this day a regional widespread new particle formation event was observed at all three measurement stations. The particle were likely formed offshore, upwind all

Aerosol dynamics in the Copenhagen urban plume

F. Wang et al.

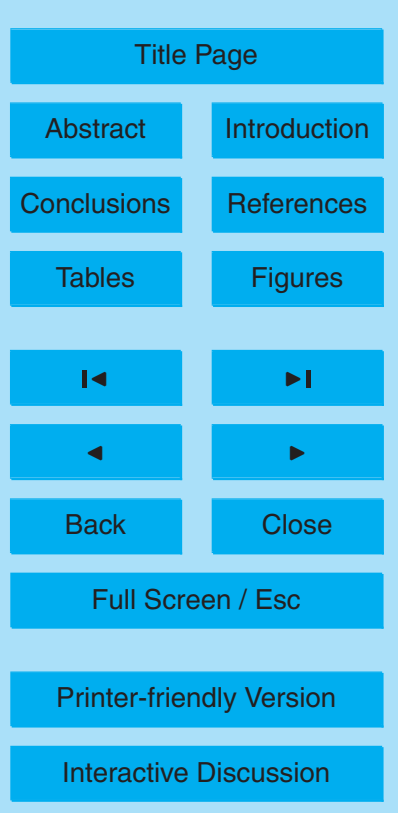

Interactive Discussion 
measurement stations, and then grew by condensation to detectable size. A few hours during the afternoon these particles were dominating the detected total particle number concentration, both at the rural and urban stations. Since these observed particles were mainly formed upwind all measurements stations, no new particle formation was 5 included in the model runs.

Figures 5 and 6 present the model results along the trajectories together with the measured data at LVBY and HCOE. The measured $\mathrm{O}_{3}, \mathrm{NO}_{\mathrm{x}}, \mathrm{NO}_{2}$, and $\mathrm{NO}$ concentrations and the particle number (PN), particle surface area (PA), and particle volume (PV) concentrations are shown by stars in Figs. 5-6 (a, b, d, e). For estimation of PV and 10 PA we use only the modeled particle size distribution below $700 \mathrm{~nm}$ to be comparable with the size range in the measured data. The accumulation of the total $\mathrm{NO}_{\mathrm{x}}$ emissions (subdivided into emissions from ship and road traffic) is presented in Figs. 5-6c, where we choose to set the value at LVBY to zero.

The measured $\mathrm{O}_{3}$ concentrations were about $10 \mathrm{ppb}$ higher at LVBY (ca. 37-39 ppb) 15 than at HCOE (ca. 27-30 ppb) for both cases A1 and A2. The modeled $\mathrm{O}_{3}$ concentrations however showed a much smaller variability at both LVBY and HCOE stations, with concentration about $31 \mathrm{ppb}$ for case $\mathrm{A} 1$ and $34 \mathrm{ppb}$ for case $\mathrm{A} 2$. The modeled $\mathrm{O}_{3}$ concentrations showed a clear day-night variation during the whole simulation period.

The model underestimated $\mathrm{NO}_{x}$ concentrations at LVBY and HCOE. The overall Average Ratios (AR, the ratio of the modeled and measured mean concentrations within cases of the same group) of $\mathrm{NO}_{x}$ values were 0.45 and 0.67 at LVBY and HCOE, respectively. The model was able to predict the trend of $\mathrm{NO}_{x}$ concentrations from LVBY to HCOE with an increase of 2.7 times and 4 times for case $A 1$ and $A 2$ respectively, in comparison to the measured $\mathrm{NO}_{x}$ concentration, which increased 2.2 times and 2.7 25 times for case $\mathrm{A} 1$ and case $\mathrm{A} 2$, respectively. It was also noteworthy that the measured $\mathrm{NO}_{2}$ values were quite similar to $\mathrm{NO}_{\mathrm{x}}$ values, while the modeled $\mathrm{NO}_{2}$ values were lower compared to $\mathrm{NO}_{x}$ values indicating that the conversion of primary emitted $\mathrm{NO}$ into $\mathrm{NO}_{2}$ by reaction with $\mathrm{O}_{3}$ is underestimated in the model as indicated before by the small change in $\mathrm{O}_{3}$ between LVBY and HCOE. In Fig. 5b, the two peaks of the modeled $\mathrm{NO}_{x}$

\section{Aerosol dynamics in the Copenhagen urban plume}

F. Wang et al.

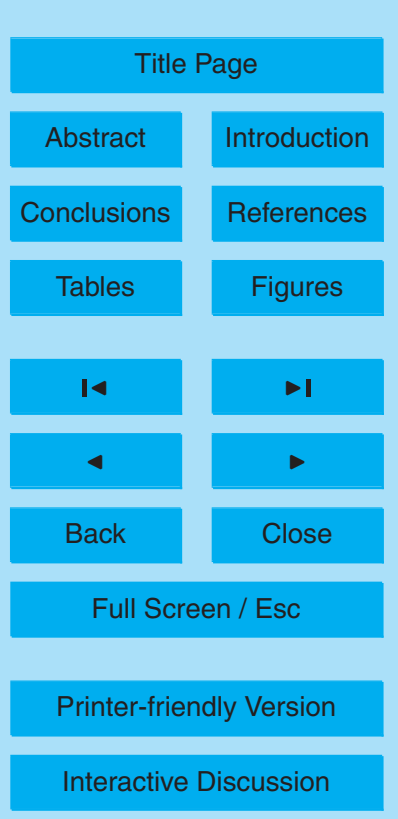


concentrations up and downwind of HCOE correspond to the increases of $\mathrm{NO}_{\mathrm{x}}$ emissions from road traffic and from ship traffic (Fig. $5 \mathrm{c}$ ). The second $\mathrm{NO}_{\mathrm{x}}$ concentration peak was as high as the first one although the increment in $\mathrm{NO}_{\mathrm{x}}$ emissions from ship traffic was only about $1 / 4$ of the increment of $\mathrm{NO}_{\mathrm{x}}$ emissions compared to road traffic.

5 This phenomenon was due to a lower vertical mixing rate caused by a lower surface roughness above the sea.

The PN, PA, PV measured by the DMPS systems and modeled were calculated for the size range $(10-700 \mathrm{~nm})$, and compared in Figs. 5-6 (d, e). The overall ARs for PN, PA, PV were 0.97, 1.26 and 1.48, respectively, at HCOE. In the first part of the 10 transport from LVBY to HCOE the $\mathrm{NO}_{\mathrm{x}}$ and the particle emissions were low and the PN decreased due to deposition and coagulation. Approaching downtown Copenhagen the modeled PN increased due to a distinct increment of particle number emissions from road traffic, which matched the measured $\mathrm{PN}$ at HCOE. The overestimation of PV might be due to an overestimation of the fraction of larger particles in the road traffic emissions for this case.

The initial particle number size distributions (PNSDs) at LVBY were interpolated from the measured PNSD data at LVBY as mentioned in section 3.3, and only slight discrepancy between "initial" and "measured" are shown in Fig. 5-9f. For case A1, the modeled PNSD at HCOE was very similar to the measured one appearing with two main modes, one nucleation mode $(15-20 \mathrm{~nm})$ and one accumulation mode at about $150 \mathrm{~nm}$. The small shift of the nucleation mode to larger diameters from $D p \approx 16 \mathrm{~nm}$ at LVBY to $D p \approx 20 \mathrm{~nm}$ at $\mathrm{HCOE}$ was also reproduced by the model. However the particle number concentration in the size range $10-30 \mathrm{~nm}$ seems underestimated (see Fig. 5f). On the contrary, for case A2 (see Fig. 6f) the particle number concentration in the size range $15-40 \mathrm{~nm}$ seems a bit overestimated at $\mathrm{HCOE}$. And the particle number concentration in the size range larger than $40 \mathrm{~nm}$ was well reproduced compared to the measured data.

\section{ACPD}

10, 8553-8594, 2010

\section{Aerosol dynamics in the Copenhagen urban plume}

F. Wang et al.

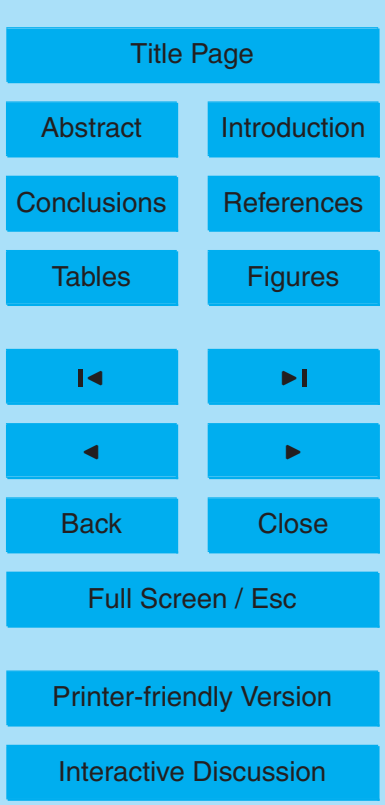




\subsection{Evaluation of simulations for $\mathrm{NO}_{\mathrm{x}}$ and particles: group $\mathrm{B}$}

In group B, three cases were chosen on 3 June, 2005, when the wind came from south-westerly directions. The air masses passed over the rural area south-west of Copenhagen (LVBY as representative station), arrived at HCOE and later over the 5 regional background area in southern Sweden (VVHL as representative station). The simulation results were compared to measured data from all three stations. In the first case the air mass arrived at HCOE at 10:00 LT. Two further cases with similar trajectories and arrival times of 13:00 LT and 16:00 LT at HCOE were simulated. Model results and their comparison with measured data at the three stations are presented in

10 Figs. 7-9 in the same form as Figs. 5-6 in Sect. 4.1 In group $B, O_{3}$ was also measured at $\mathrm{VVHL}$ and the modeled $\mathrm{O}_{3}$ values were close to the measurements, following well the trend at the three stations. The overall ARs were 1.07, 1.31 and 1.13 at LVBY, HCOE and VVHL, respectively.

The overall ARs for $\mathrm{NO}_{\mathrm{x}}$ concentrations were 0.79 and 0.80 at LVBY and HCOE, 15 respectively. The $\mathrm{NO}_{\mathrm{x}}$ concentrations show several peaks or increases that are related to emissions from road traffic on the path before arriving at HCOE as also seen for the cases $A 1$ and $A 2$. About half an hour after passing HCOE there is a peak visible in all modeled cases that is connected to ship emission. Further downwind of HCOE there are again road emissions from the Swedish land sources. Especially for case 20 B3 (see Fig. 9b), there is a distinct peak for $\mathrm{NO}_{x}$ at 17:20 LT, corresponding to the $\mathrm{NO}_{x}$ emission from a stationary point source at the western coast of southern Sweden, where southern Landskrona industrial harbor area is located. Landskrona is a city with a population of approximately 40000 people. The modeled $\mathrm{NO}_{\mathrm{x}}$ results gave lower concentrations compared to the measurements except for case B3 as can be seen by 25 the ARs. The $\mathrm{NO}_{\mathrm{x}}$ concentration was nearly reproduced by the model at both LVBY and HCOE station for case B3, which indicates that the atmospheric dispersion was reasonably simulated in the model.

The overall ARs for PN, PA and PV were 0.74, 0.84, and 0.77 at HCOE, and 0.93,

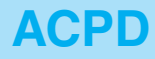

$10,8553-8594,2010$

Aerosol dynamics in the Copenhagen urban plume

F. Wang et al.

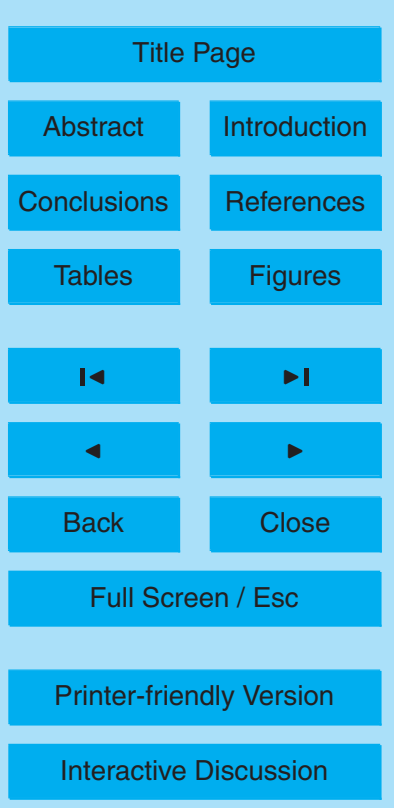


0.83, and 0.70 at VVHL respectively. At about 15:30 LT, the trajectory (B3) passed over a highway in western Copenhagen and the $\mathrm{NO}_{\mathrm{x}}$ emission from road traffic was almost twice as high compared to the case B1 and B2 (see Figs. 7-9c). The high modeled concentration peaks of $\mathrm{NO}_{\mathrm{x}}$ and $\mathrm{PN}, \mathrm{PA}$, and $\mathrm{PV}$ were responding to this $\mathrm{NO}_{\mathrm{x}}$ emission

5 increment from road traffic, which was typical for a crossing of several highways and could be spatially resolved owing to the $1 \times 1 \mathrm{~km}$ grid used as emission inventory here. It has to be stated that with respect to the uncertainty in trajectory analysis it can not be concluded if the experimentally observed air mass matched crossing of several highways.

10 Modeled and measured PNSD at all three stations are shown in Figs. 7-9f for comparison. In this group of cases, the measured particle number size distribution showed a dominating mode at $60-80 \mathrm{~nm}$ and a second one at $150-300 \mathrm{~nm}$ diameter depicting a similar shape as the averaged PNSD in Fig. 3b. The measured data showed that there were higher concentrations of particles at about $20-50 \mathrm{~nm}$ at HCOE compared to LVBY and VVHL, which might be caused mainly by the contribution from road traffic (see Fig. 4). The model was partly able to reproduce this traffic contribution at HCOE to some extent but shows a tendency of underestimating PNSD particularly at cases B1 and B2, while the case B3 shows the best agreement. This behavior was also shown for $\mathrm{NO}_{\mathrm{x}}$ and $\mathrm{PN}, \mathrm{PA}$ and $\mathrm{PV}$. This underestimation in some cases might be due to an underestimation of the emissions or an too high dispersion caused e.g. by a too high boundary layer.

At VVHL, the PNSD appeared to be similar to LVBY as the traffic contribution of ultrafine particles were reduced due to deposition and coagulation sinks during transport over a distance of $50 \mathrm{~km}$ downwind from the Copenhagen downtown area. In general the background concentration at VVHL for the B cases was lower than at LVBY. The measured PNSD at 13:00 LT at HCOE for case B2 (Fig. 8f) show a mode at 25-30 nm, most likely due to instantaneous local emissions, which were not reproduced by the model. The particles at the higher end of the size range $(D p>300 \mathrm{~nm})$ were underestimated by the model cases B1 and B2. These particles might be formed from local

\section{Aerosol dynamics in the Copenhagen urban plume}

F. Wang et al.

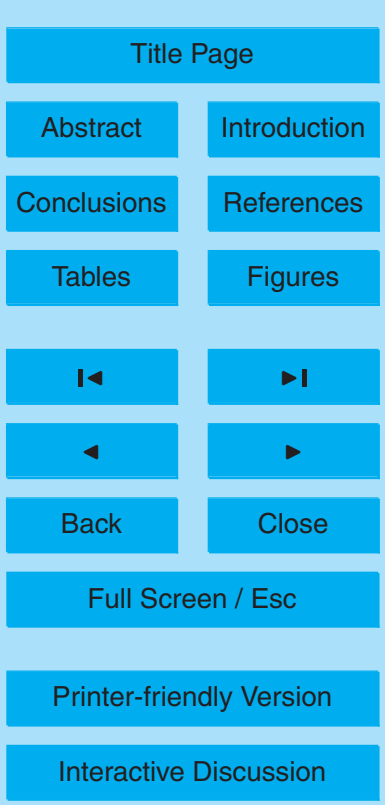


sources, not captured by the average size-resolved traffic number emission factors. For case B3, the initial PNSD at LVBY showed a coarse mode at 200-300 $\mathrm{nm}$ and the modeled PNSD at HCOE and VVHL showed a similar mode. The measured PNSD at VVHL appeared with a coarse mode at about $300-400 \mathrm{~nm}$, most likely due to local 5 sources.

Figure 10 illustrates the vertical concentration profile of $\mathrm{NO}_{\mathrm{x}}$ and $\mathrm{PN}$ for case $\mathrm{B} 3$. The boundary layer height was between $1000 \mathrm{~m}$ and $1200 \mathrm{~m}$. The two peaks of $\mathrm{NO}_{\mathrm{x}}$ at the surface layer corresponded to the two $\mathrm{NO}_{\mathrm{x}}$ emission increments at 15:30 LT and 17:20 LT local time caused by local traffic emission (see Fig. 9c). At all other 10 times when the local emissions were even smaller, $\mathrm{NO}_{\mathbf{x}}$ emissions were well mixed in the boundary layer. The PN concentration was also distinctly higher at the surface layer corresponding to the $\mathrm{NO}_{\mathrm{x}}$ emissions from road traffic, which were proportional to particle number emissions from road traffic. Apart from this peak at the surface, the PN concentration within the boundary layer depicted the similar magnitude as in the

15 surface layer. In the free troposphere (over the boundary layer) the PN concentration reaches values of $4 \times 10^{3}$ particles $\mathrm{cm}^{-3} 10 \mathrm{~h}$ after LVBY, which is slightly lower than in the boundary layer.

\subsection{Aerosol dynamics process study}

In this section, we quantitatively evaluate the effects of different aerosol dynamic pro20 cesses. Simulations were carried out including all the processes and in a next step switching off one process at a time. An overview of this analysis is shown in Table 2. The effect of different dynamic processes was evaluated by the ratio of the result obtained excluding the individual process to the result including this process. The interaction of different aerosol dynamic processes was not evaluated. This study was carried

out for case B3 and the results are illustrated in Fig. 11 and Fig. 12. Figure 11 shows the concentrations of PN, PV and PA and the relative increase or decrease of these values in percent when the individual process was excluded. The change in particle number size distribution at HCOE and VVHL for case B3 is also shown in Fig. 12 for

Aerosol dynamics in the Copenhagen urban plume

F. Wang et al.

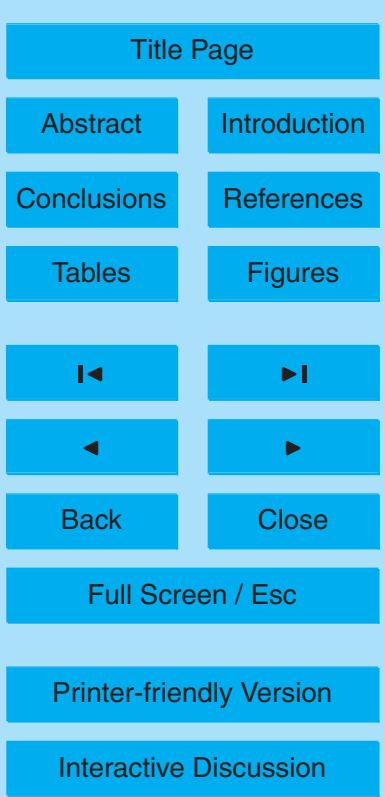


the different simulations.

Dry deposition decreases the total number concentration of particles and together with dilution and evaporation these are the only processes which also decrease the total volume concentration. When dry deposition was switched off, PN concentration 5 increased by about $20 \%$ after $6 \mathrm{~h}$ transport downwind from LVBY (see Fig. 11), while PA and PV concentrations increased by about $10 \%$ and $5 \%$, respectively. Dry deposition mainly affects ultrafine particles (diameter $<100 \mathrm{~nm}$ ) and large accumulation mode particles (diameter $>300 \mathrm{~nm}$ ). The ultrafine particles are effectively deposited by Brownian diffusion and the coarse particles are deposited due to sedimentation (Zhang et 10 al., 2001). The ultrafine particle number concentration showed highest differences with the absence of deposition process at $\mathrm{HCOE}$, especially for particles smaller than $30 \mathrm{~nm}$ in diameter (see Fig. 12a).

The coagulation effectively decreased the total particle number concentration while it was not altering the particle volume concentration. The absence of coagulation pro15 cesses resulted in about $20 \%$ increase of PN concentration $6 \mathrm{~h}$ downwind of LVBY (see Fig. 11). In Fig. 12b it is evident that coagulation had largest effect for particles smaller than $30 \mathrm{~nm}$ in diameter.

The modeled condensation growth was slow, and only indirectly affected the PN concentration after longer time periods by decreasing the coagulation and dry deposition losses of the smallest particles. The condensation process resulted in an increase of PA and PV by roughly $7 \%$ after $6 \mathrm{~h}$ transport (see Fig. 11). When all processes were switched off the simulation results showed an increase of PN concentration of about $40 \%$, while the PA and PV concentration changed very little by less than $3 \%$ (see Fig. 11). As expected, the difference in PN concentrations appeared higher with increasing distance from LVBY. Within the distance from LVBY to HCOE (about 1 to $2 \mathrm{~h}$ ) the aerosol dynamics had only small influence on the results, and the emissions clearly dominated (see Fig. 12a). At VVHL, after about $4 \mathrm{~h}$ transport, the aerosol dynamic processes had much larger influence on the particle number size distribution compared to HCOE, where emissions in the Copenhagen area dominated (see Fig. 12b).

\section{Aerosol dynamics in the Copenhagen urban plume}

F. Wang et al.

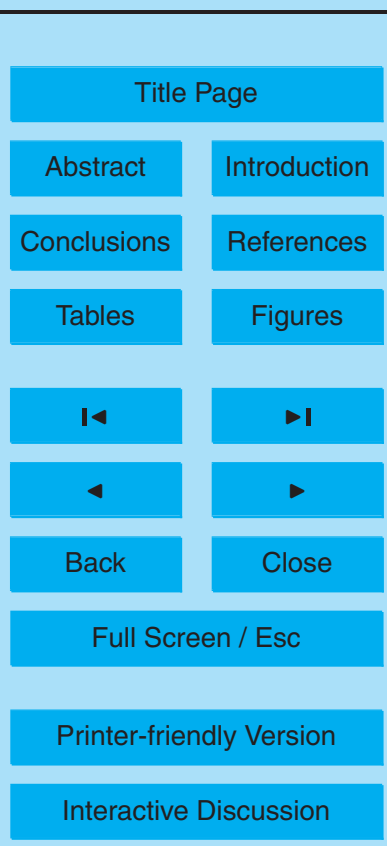




\subsection{Uncertainty and sensitivity study}

Table 3 summarizes the estimated uncertainties and impact of individual processes for the modeled PN concentration at the urban background (HCOE) and the downwind regional background (VVHL) based on our calculations. First of all the meteorological 5 conditions had a large impact on the model results. The HYSPLIT trajectory model provides very coarse meteorological data with a spatial resolution of $100 \mathrm{~km}$, which has limited the interpretation of the results to the same magnitude of scale. We compared the mixing height, which is one of the most important parameters affecting the predicted concentration levels from the HYSPLIT model with the Danish forecast model system

10 THOR (Brandt et al., 2001) for the same periods as our simulations. The mixing height predicted by THOR was only about half of the value obtained by the HYSPLIT trajectory model for case B3. We studied the effect of a varying mixing height in an individual case study by setting the mixing height to the one obtained by the Danish forecast model (around half of the value obtained by HYSPLIT) for case B3 and air masses from LVBY to HCOE. The results showed that the PN concentration increment was lowered by $1 / 3$ compared to the original case between the two stations. As a consequence, this increment was significantly lower than the $\mathrm{NO}_{x}$ increment (about one time) due to a higher effectiveness of aerosol dynamic processes. This example highlights the importance of highly resolved meteorological input parameters and their impact on the simulation results.

For all case studies there was a rapid increase of the $\mathrm{NO}_{x}$ concentration over the Copenhagen area. The magnitude of the increase and the variability within the Copenhagen area differed significantly between the cases. This variability along the trajectories could not be explained by temporal variations in emissions or meteorology alone, but had rather more to do with large spatial variability of the $\mathrm{NO}_{\mathrm{x}}$ emissions within the Copenhagen area. To study this we carried out a 2-D model simulation, with a horizontal domain of $20 \mathrm{~km}$ and a spatial resolution of $1 \mathrm{~km}$. From this we found that the trajectory path significantly affected the $\mathrm{PN}$ and $\mathrm{NO}_{x}$ concentrations, while the horizon-

10, 8553-8594, 2010

Aerosol dynamics in the Copenhagen urban plume

F. Wang et al.

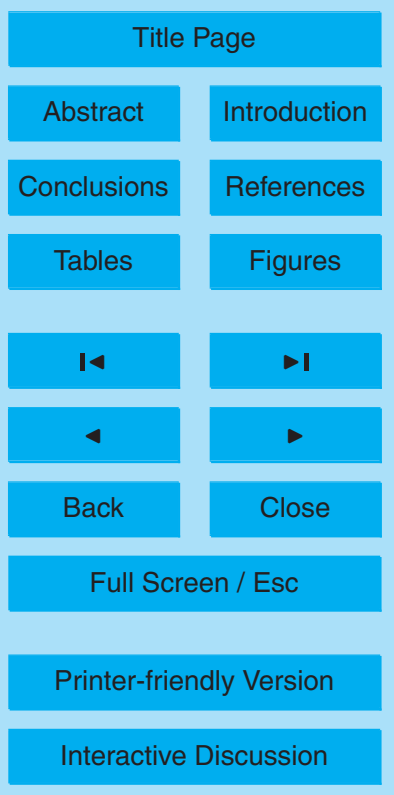

Interactive Discussion 
tal mixing between adjacent grid cells only had a smaller impact on the results within 2-3 h downwind of HCOE. Deviations of a few kilometers between the actual and modeled trajectory path before HCOE could therefore at least partly explain the relatively large discrepancy between the modeled and measured PN concentration at HCOE, 5 for two out of five case studies. The uncertainty in the exact trajectory path seemed to have much larger impact than the horizontal mixing within the study region. The primary advantage of using the 2-D model instead of the 1-D model is rather more that the 2-D model pin-pointed the uncertainties due to a wrong trajectory path than an increase of accuracy using this model.

10 Other variables with potential large effect but of moderate uncertain are: the time which the trajectories spend over the urban region, $\mathrm{NO}_{\mathrm{x}}$ emissions, $\mathrm{PN}$ from $\mathrm{NO}_{\mathrm{x}}$ emission ratio and temporal variability in the emissions. All these variables affect the $\mathrm{NO}_{\mathrm{x}}$ and primary particle emissions, and thereby indirectly the $\mathrm{PN}$ and $\mathrm{NO}_{\mathrm{x}}$ concentrations. The emission factor for the road particle number size distribution and for the ratio of PN to $\mathrm{NO}_{\mathrm{x}}$ were averaged values obtained from downtown Copenhagen. It might not have been suitable for the entire simulation area.

In our study, we selected days with clear sky for the simulations, as there is limited knowledge about cloud micro-physics and data on exact cloud height and coverage. Therefore uncertainties with these processes together with wet deposition can be neglected in this study. The dry deposition velocity largely depends on the surface type (Pryor et al., 2008) and stability of the surface layer, which was not specifically studied in this region. Therefore the modeled dry deposition velocity has a large uncertainty and together with the uncertain mixing height it gives large uncertainties in the modeled dry deposition losses within the boundary layer. However, the dry deposition has small influence on the particle number concentration and size distribution upwind of HCOE (because of the small time scale) and therefore these large uncertainties has small influence on the result at HCOE. The same is true for condensation. Coagulation is the aerosol dynamic process which is least uncertain. Also this process has small impact for the model results at HCOE. At VVHL $1-2 \mathrm{~h}$ downwind of HCOE the aerosol

\section{Aerosol dynamics in the Copenhagen urban plume}

F. Wang et al.

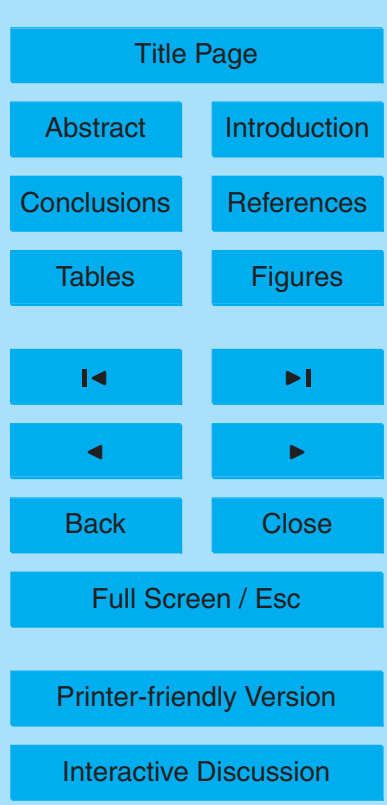


dynamic processes are more important for the modeled particle number size distribution, and uncertainties with these processes become of more concern. However, also on this spatial scale the meteorological conditions and primary particle emissions over the urban area are more important than the aerosol dynamics.

5 The particle condensation growth rate was estimated to be less than $1 \mathrm{~nm}$ per hour, which partly can be explained by evaporation of nitrate during daytime driven by changes in temperature, relative humidity and the sulfuric acid concentration. While the inorganic gas and particle chemistry is relatively well known, there is still very limited knowledge of the Secondary Organic Aerosol (SOA) precursors in urban envi10 ronments. In ADCHEM, benzene, toluene and xylene are the only anthropogenic gas phase species, which were used in the SOA formation mechanism through their oxidation products. These are likely among the most important, however in reality there will be hundreds of organic compounds which can contribute to SOA formation.

\section{Discussion and conclusions}

15 In this study we have used the gas phase and physical particle data obtained during 2005 from three stations to investigate the processes affecting the particle number size distribution in the Copenhagen urban environment and close to the Copenhagen area by an aerosol dynamic chemistry model (ADCHEM). ADCHEM was provided with local primary particle number emissions from road traffic, ship transportation and wood 20 stove combustion and simulated particle number concentrations and particle number size distributions on a regional scale. The studies conducted showed that the model could reproduce the trend and concentrations of $\mathrm{NO}_{\mathrm{x}}$, PN, PA, PV during 3 out of 5 case studies (A1, A2 and B3). The average ratio of modeled versus measured concentrations ranged between 0.5 and 2 for these species. When the measured $\mathrm{NO}_{\mathrm{x}}$ values 25 were very low or very high, the average ratios for $\mathrm{NO}_{\mathrm{x}}$ showed the highest bias. On 6 June (cases $\mathrm{A} 1$ and $\mathrm{A} 2$ ), the $\mathrm{NO}_{\mathrm{x}}$ concentrations were very low since the air mass was arriving from the northern Atlantic region with low $\mathrm{NO}_{\mathrm{x}}$ emissions. The results

\section{Aerosol dynamics in the Copenhagen urban plume}

F. Wang et al.

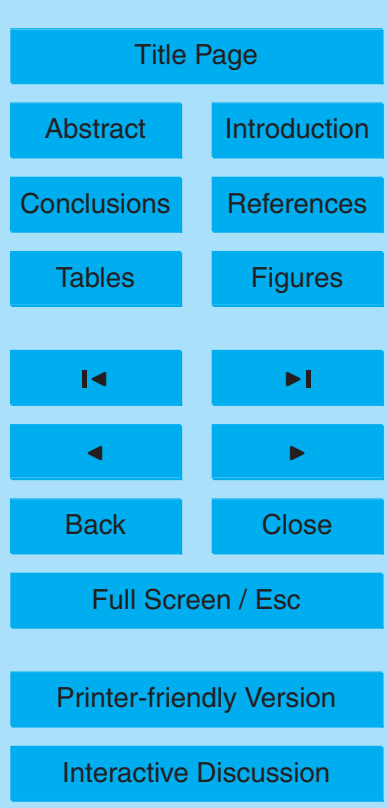


indicated that ADCHEM was able to numerically compute the atmospheric dispersion with realistic values using $\mathrm{NO}_{\mathrm{x}}$ as a tracer.

Based on the model results we found that the PN concentration in the higher boundary layer could reach the same magnitude as the PN concentration in the surface layer 5 apart from recent emissions around a hot spot location. We studied the impact of individual dynamic processes on the development of physical particle parameters. During the relatively short $(1-1.5 \mathrm{~h})$ transport between the first two stations upwind Copenhagen the aerosol dynamic processes had small influence on the physical properties of the particle population. Here the primary particle emissions and vertical mixing which 10 has the largest impact on the submicron size distribution. Downwind of the urban area the aerosol dynamic processes became more important. But the lifetime of the freshly emitted road particle emission can vary considerably depending on the background aerosol properties. If clean air masses reach the urban area, the coagulation sink of the freshly emitted road emissions will be relatively small compared to the case when the air mass arrive form more polluted areas over continental Europe.

We conclude from our study that aerosol dynamic processes cannot be neglected when dispersion models are used to predict particle number size distribution downwind urban areas with relatively low emissions, however upwind of and at the urban background when emissions are high the aerosol dynamic processes have minor influence on the model results.

We were not able to model the processes taking place on shorter time scales (seconds to minutes) since we could not resolve spatial scales lower than $100 \mathrm{~m}$ in our model runs due to limitations in the emission inventories and in computing time. Hence, our results cannot be compared to those studies where this transformation has been studied in more detail on this scale. Instead our results are especially useful for the parameterization of aerosol dynamic processes on the urban/regional scale with relevance for investigations of human exposure and climate effects.

Acknowledgements. The authors thank P. Wåhlin for providing the Danish measurement data and S. Gustafsson for providing the Sweden emission inventory data.

\section{Aerosol dynamics in the Copenhagen urban plume}

F. Wang et al.

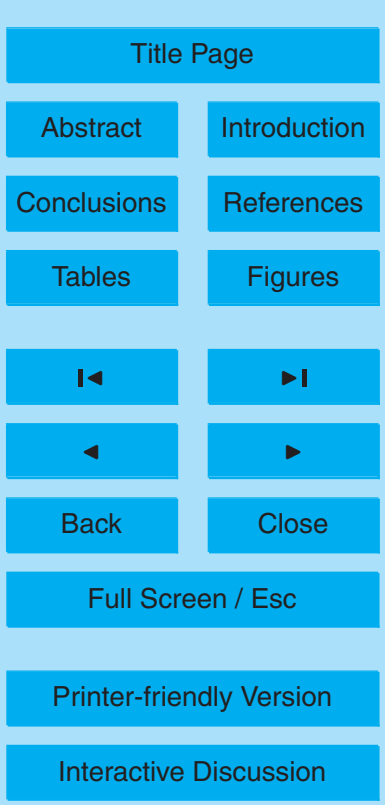

Interactive Discussion 


\section{References}

Beddows, D. C. S. and Harrison, R. M.: Comparison of average particle cnumber emission factors for heavy and light duty vehicles derived from rolling chassis dynamometer and field studies, Atmos. Environ., 42, 7954-7966, 2008.

5 Brandt, J., Christensen, J. H., Frohn, L. M., and Zlatev, Z.: Operational air pollution forecast modelling using the THOR system, Phys. Chem. Earth B, 26, 117-122, 2001.

Brickman, D. and Smith, P. C.: Lagrangian stochastic modeling in coastal oceanography, J. Atmos. Ocean. Tech., 19, 83-99, 2002.

Gidhagen, L., Johansson, C., Ström, J., Kristensson, A., Swietlicki, E., Pirjola, L., and Hansson, 10 H. C.: Model simulation of ultrafine particles inside a road tunnel, Atmos. Environ., 37, 20232036, 2003.

Gidhagen, L., Johansson, C., Langner, J., and Olivares, G.: Simulation of $\mathrm{NO}_{\mathrm{x}}$ and ultrafine particles in a street canyon in Stockholm, Sweden, Atmos. Environ., 38, 2029-2044, 2004.

Guenther A.: Seasonal and Spatial Variations in Natural Volatile Organic Compound Emissions, 15 Ecol. Appl., 7, 34-45, 1997.

Gustafsson, S.: Construction and validation of an emission data base for air pollutants in Scania, Sweden, with base year 2001. (Uppbyggnad och validering av emissionsdatabas avseende luftföroreningar för Skåne med basår 2001) Licentiate Degree Dissertation, Lund University, department of Physical Geography and Ecosystem Analysis, ISBN: 978-9185793-00-6, 2007 (in Swedish with English summary and 4 appended English papers).

Hussein, T., Dal Maso, M., Petaja, T., Koponen, I. K., Paatero, P., Aalto, P. P., Hämeri, K., and Kulmala M.: Evaluation of an automatic algorithm for fitting the particle number size distributions, Boreal Environ. Res., 10, 337-355, 2005.

Intergovernmental Panel on Climate Change: Climate Change 2007. The physical science basis; IPCC Secretariant, Geneva, 2007.

Jacobson, M. Z. and Seinfeld, J. H.: Evolution of nanoparticle size and mixing state near the point of emission, Atmos. Environ., 38, 1839-1850, 2004.

Imhof, D., Weingartner, E., Ordonez, C., Gehrigt, R., Hill, N., Buchmann, B., and Baltensperger, U.: Real-world emission factors of fine and ultrafine aerosol particles for different traffic situations in Switzerland, Environ. Sci. Technol., 39, 8341-8350, 2005.

Kemp, K., Ellermann, T., Brandt, J., Christensen, J., Ketzel, M., and Jensen, S.S.: The Danish Air Quality Monitoring Programme. Annual Summary for 2007. National Environmental

Aerosol dynamics in the Copenhagen urban plume

F. Wang et al.

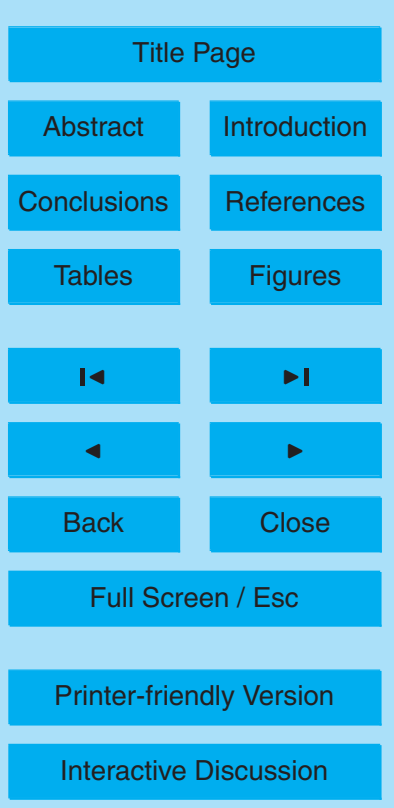

Interactive Discussion 
Research Institute, Aarhus University, Roskilde, Denmark, NERI Technical Report No. 681, 47 pp., 2008.

Keogh, D. U., Kelly J., Mengersen, K., Jayaratne, R., Ferreira, L., and Morawska, L.: Derivation of motor vehicle tailpipe particle emission factors suitable for modelling urban fleet emissions 5 and air quality assessments, Environ. Sci. Pollut. Res., 17, 724-739, 2010.

Kerminen, V.-M., Pakkanen, T. A., Mäkelä, T., Hillamo, R. E., Sillanpää, M., Rönkko, T., Virtanen, A., Keskinen, J., Pirjola, L., Hussein, T., and Hämeri, K.: Development of particle number size distribution near a major road in Helsinki during an episodic inversion situation, Atmos. Environ., 41, 1759-1767, 2007.

10 Ketzel, M. and Berkowicz, R.: Modelling the fate of ultrafine particles from exhaust pipe to rural background: an analysis of time scales for dilution, coagulation and deposition, Atmos. Environ., 38, 2639-2652, 2004a.

Ketzel, M., Wåhlin, P., Kristensson, A., Swietlicki, E., Berkowicz, R., Nielsen, O. J., and Palmgren, F.: Particle size distribution and particle mass measurements at urban,near-city and rural level in the Copenhagen area and Southern Sweden, Atmos. Chem. Phys., 4, 281-292, 2004b, http://www.atmos-chem-phys.net/4/281/2004/.

Ketzel, M. and Berkowicz, R.: Multi-plume aerosol dynamics and transport model for urban scale particle pollution, Atmos. Environ., 39, 3407-3420, 2005.

Kittelson, D. B., Watts, W. F., and Johnson, J. P.: Nanoparticle emissions on Minnesota highways, Atmos. Environ., 38, 9-19, 2004.

Kittelson, D. B., Watts, W. F., and Johnson, J. P.: On-road and laboratory evaluation of combustion aerosols - Part 1: Summary of diesel engine results, Aerosol Sci., 37, 913-930, 2006.

Kristensson, A., Dal Maso, M., Swietlicki, E., Hussein, T., Zhou, J., Kerminen, V.-M., and Kulmala, M.: Characterization of new particle formation events at a background site in Southern Sweden: relation to air mass history, Tellus, 60B, 330-344, 2008.

Löndahl, J., Massling, A., Swietlicki, E., Bräuner, E. V., Ketzel, M., Pagels, J., and Loft, S.: Experimentally Determined Human Respiratory Tract Deposition of Airborne Particles at a $30 \quad$ Busy Street, Environ. Sci. Technol., 43, 4659-4664, 2009.

Martensson, E. M., Nilsson, E. D., de Leeuw, G., Cohen, L. H., and Hansson, H. C.: Laboratory simulations and parameterization of the primary marine aerosol production, J. Geophys. Res.-Atmos., 108, 4297, doi:10.1029/2002JD002263, 2003.

Aerosol dynamics in the Copenhagen urban plume

F. Wang et al.

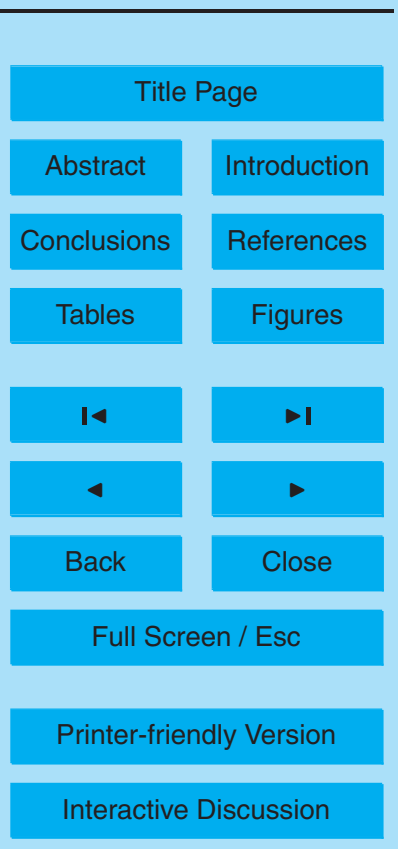


Malm, W. C., Day, D. E., Kreidenweis, S. M., Collett, J. L., and Lee, T.: Humidity-dependent optical properties of fine particles during the Big Bend regional aerosol and visibility observational study, J. Geophys. Res.-Atmos., 108, 4279, doi:10.1029/2002JD002998, 2003.

Morawska, L., Ristovski, Z., Jayaratne, E. R., Keogh, D. U., and Ling, X.: Ambient nano and $5 \quad$ ultrafine particles from motor vehicle emissions: Characteristics, ambient processing and implications on human exposure, Atmos. Environ., 42, 8113-8138, 2008.

Mueller, J. A. and Veron, F.: A Lagrangian Stochastic Model for Heavy Particle Dispersion in the Atmospheric Marine Boundary Layer, Bound.-Lay. Meteorol., 130, 229-247, 2009.

Petzold, A., Hasselbach, J., Lauer, P., Baumann, R., Franke, K., Gurk, C., Schlager, H., and Weingartner, E.: Experimental studies on particle emissions from cruising ship, their characteristic properties, transformation and atmospheric lifetime in the marine boundary layer, Atmos. Chem. Phys., 8, 2387-2403, 2008, http://www.atmos-chem-phys.net/8/2387/2008/.

Pohjola, M. A., Pirjola, L., Karppinen, A., Härknen, J., Korhonen, H., Hussein, T., Ketzel, M., and Kukkonen, J.: Evaluation and modelling of the size fractionated aerosol particle number concentration measurements nearby a major road in Helsinki-Part I: Modelling results within the LIPIKA project, Atmos. Chem. Phys., 7, 4065-4080, 2007,

http://www.atmos-chem-phys.net/7/4065/2007/.

Pope, C. A. and Dockery, D. W.: Health effects of fine particulate air pollution: Lines that connect, J. Air Waste Manage. Assoc., 56, 709-742, 2006.

Pryor, S. C., Gallagher, M., Sievering, H., Larsen, S. E., Barthelmie, R. J., Birsan, F., Nemitz, E., Rinne, J., Kulmala, M., Groenholm, T., Taipale, R., and Vesala, T.: A review of measurement and modelling results of particle atmosphere-surface exchange, Tellus B, 60, 42-75, 2008.

Roldin, P., Swietlicki, E., Schurgers, G. and Arneth, A.: Development, evaluation and application of the aerosol dynamic and gas phase chemistry model ADCHEM, to be submitted to Atmos. Chem. Phys., 2010a.

Roldin, P. , Swietlicki, E. , Massling, A. , Kristensson, A., Löndahl, J., Eriksson, A., Pagels, J., and Gustafsson, S.: Aerosol ageing in an urban plume- Implications for climate and health, to be submitted to Atmos. Chem. Phys., 2010b.

30 Rolph, G. D.: Real-time Environmental Applications and Display sYstem (READY) Website (http://www.arl.noaa.gov/ready/hysplit4.html), NOAA Air Resources Laboratory, Silver Spring, MD, 2003.

Simpson, D., Winiwarter, W., Börjesson, G., Cinderby, S., Ferreiro, A., Guenther, A., Hewitt, 
N., Janson, R., Khalil, M. A. K., Owen, S., Pierce, T. E., Puxbaum, H., Shearer Skiba, M. U., Steinbrecher, R., Tarrasón, L., and Öquist, M. G.: Inventoring emissions from nature in Europe, J. Geophys. Res.-Atmos., 104, 8113-8152, 1999.

Simpson, D., Fagerli, H., Jonson, J. E., Tsyro, S., Wind, P., and Tuovinen, J. P.: Transboundary 5 Acidification, Eutrophication and Groud Level Ozone in Europe, Part I, Unified EMEP Model Description, EMEP Status Report, 0806-4520, 2003.

Spracklen, D. V., Carslaw, K. S., Kulmala, M., Kerminen, V.-M., Mann, G. W., and Sihto, S.L.: The contribution of boundary layer nucleation events to total particle concentrations on regional and global scales, Atmos. Chem. Phys., 6, 5631-5648, 2006,

$10 \mathrm{http}: / /$ www.atmos-chem-phys.net/6/5631/2006/.

Steinbrecher, R., Smiatek, G., Köble, R., Seufert, G., Theloke, J., Hauff, K.; Ciccioli, P., Vautard, R., and Curci, G.: Intra- and inter-annual variability of VOC emissions from natural and seminatural vegetation in Europe and neighbouring countries, Atmos. Environ., 43, 1380-1391, 2009.

15 Su, Y. X., Sipin, M. F., Spencer, M. T., Qin, X. Y., Moffet, R. C., Shields, L. G., Prather, K. A., Venkatachari, P., Jeong, C. H., Kim, E., Hopke, P. K., Gelein, R. M., Utell, M. J., Oberdorster, G., Berntsen, J., Devlin, R. B., and Chen, L. C.: Real-time characterization of the composition of individual particles emitted from ultrafine particle concentrators, Aerosol Sci. Tech., 40, 437-455, 2006.

20 Uhrner, U., von Löis, S., Vehkamäi, H., Wehner, B., Bräel, S., Hermann, M., Stratmann, F., Kulmala, M., and Wiedensohler, A.: Dilution and aerosol dynamics within a diesel car exhaust plume - CFD simulations of on-road measurement conditions, Atmos. Environ., 41, 7440-7461, 2007.

Vestreng, V., Rigler, E., Adams, M., Kindbom, K., Pacyna, J. M., van der Gon, D., Reis, H. S., and Traynikov, O.: Inventory review 2006, Emission data reported to LRTAP and NEC Directive, Stage 1, 2 and 3 review and Evaluation of Inventories of HM and POPs. EMEP/MSC-W Technical Report 1/2006 ISSN 1504-6179, 2006.

Wåhlin, P., Olesen, H. R., Bossi, R., and Stubkjær, J. : Air pollution from residential wood combustion in a Danish village - Measuring campaign and analysis of results. National Environmental Research Institute, Aarhus University, Roskilde, Denmark, NERI Technical Report No. 777, 2010.

Wang, F., Ketzel, M., Ellermann, T., Wåhlin, P., Jensen, S. S., Fang, D., and Massling, A.: Particle number, particle mass and $\mathrm{NO}_{\mathrm{x}}$ emission factors at a highway and an urban street

\section{Aerosol dynamics in the Copenhagen urban plume}

F. Wang et al.

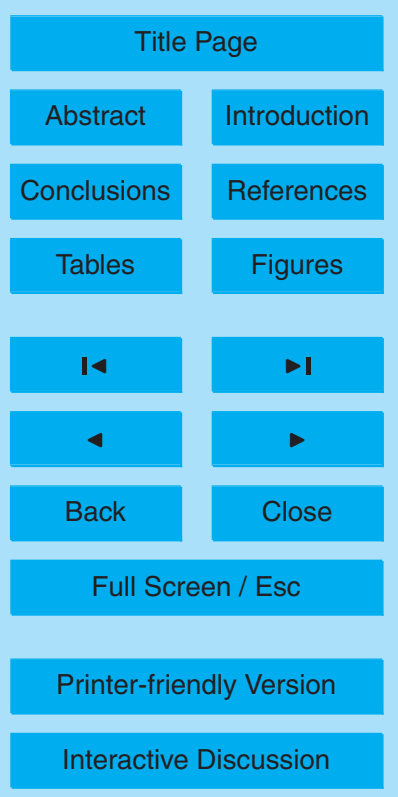


in Copenhagen, Atmos. Chem. Phys., 10, 2745-2764, 2010, http://www.atmos-chem-phys.net/10/2745/2010/.

Wehner, B., Birmili, W., Gnauk, T., and Wiedensohler, A.: Particle number size distributions in a street canyon and their transformation into the urban-air background: measurements and a simple model study, Atmos. Environ., 36, 2215-2223, 2002.

Weichenthal, S., Dufresne, A., and Infante-Rivard, C.: Indoor ultrafine particles and childhood asthma: exploring a potential public health concern, Indoor Air, 17, 81-91, 2007.

Weil, J. C., Sullivan, P. P., and Moeng, C. H.: The use of large-eddy simulations in Lagrangian particle dispersion models, J. Atmos. Sci., 61, 2877-2887, 2004.

10 Yeung P. K.: Lagrangian investigations of turbulence, Ann. Rev. Fluid Mech., 34, 115-142, 2002.

Zhang, K. M. and Wexler, A. S.: Modeling the number distributions of urban and regional aerosols: theoretical foundations, Atmos. Environ., 36, 1863-1874, 2002.

Zhang, K. M., Wexler, A. S., Zhu, Y. F., Hinds, W. C., and Sioutas, C.: Evolution of particle number distribution near roadways. Part II: the "Road-to-Ambient" process, Atmos. Environ., 38, 6655-6665, 2004.

Zhang, K. M., Wexler, A. S., Niemeier, D. A., Zhu, Y. F., Hinds, W. C., and Sioutas, C.: Evolution of particle number distribution near roadways. Part III: Traffic analysis and on-road size resolved particulate emission factors, Atmos. Environ., 39, 4155-4166, 2005.

Zhang, L., Gong, S., Padro, J., and Barrie, L.: A size-segregated particle dry deposition scheme for an atmospheric aerosol module, Atmos. Environ., 35, 549-560, 2001.

Zhu, Y., Hinds, W. C., Kim, S., Shen, S., and Sioutas, C.: Study of ultrafine particles near a major highway with heavy-duty diesel traffic, Atmos. Environ., 36, 4323-4335, 2002.

Aerosol dynamics in the Copenhagen urban plume

F. Wang et al.

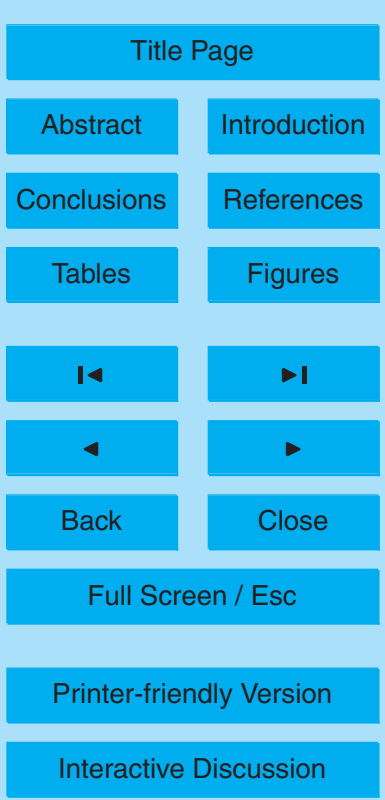




\section{ACPD}

10, 8553-8594, 2010

Table 1. Parameterized particle number size distribution and chemical composition for emissions from road traffic (Wang et al., 2009), ship traffic (Petzol et al., 2008) and wood stoves (Wåhlin et al., 2010). Mode geometric mean diameter, standard deviation, and the percent fraction of the number concentration in each mode are denoted by GMD, $\sigma_{g}$, and $\mathrm{N}$ respectively.

\begin{tabular}{llrrrrr}
\hline Source type & Parameter & Mode 1 & Mode 2 & Mode 3 & Mode 4 & Mode 5 \\
\hline Traffic & GMD $(\mathrm{nm})$ & 15.8 & 36.1 & 96 & 257 & 450 \\
& $\sigma_{g}$ & 1.68 & 1.77 & 1.68 & 1.60 & 1.70 \\
\multirow{5}{*}{ Ship } & $\mathrm{N}(\%)$ & 46.93 & 36.6 & 15.28 & 1.19 & 0.00001 \\
& GMD $(\mathrm{nm})$ & 14 & 90 & & & \\
\multirow{5}{*}{ Woodburning } & $\sigma_{g}$ & 1.45 & 1.52 & & & \\
& $\mathrm{~N}(\%)$ & 43.75 & 56.25 & & & \\
& GMD (nm) & 13 & 28 & 65 & 166 & 300 \\
& $\sigma_{g}$ & 1.51 & 1.86 & 1.81 & 2.00 & 2.00 \\
& $\mathrm{~N}(\%)$ & 15.6 & 43 & 27.7 & 13.7 & 0.00001 \\
\hline
\end{tabular}

Aerosol dynamics in the Copenhagen urban plume

F. Wang et al.

Title Page

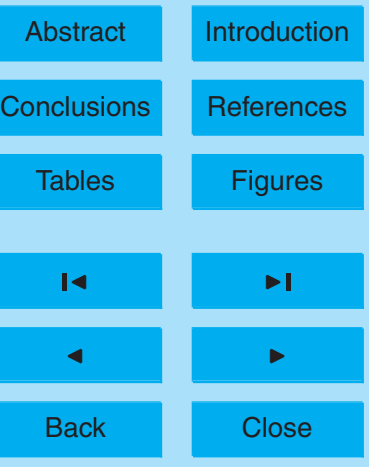

Full Screen / Esc

Printer-friendly Version

Interactive Discussion 


\section{ACPD}

$10,8553-8594,2010$

\section{Aerosol dynamics in} the Copenhagen urban plume
F. Wang et al.

Table 2. Overview of model simulations with different combination of dynamic processes included, (+ means that the process was included, - means that the process was excluded).

\begin{tabular}{lccccc}
\hline Short name & Deposition & Coagulation & Condensation & Dilution & Emission \\
\hline All processes & + & + & + & + & + \\
No_dep & - & + & + & + & + \\
No_coag & + & - & + & + & + \\
No_cond & + & + & - & + & + \\
None_process & - & - & - & + & + \\
\hline
\end{tabular}

Title Page

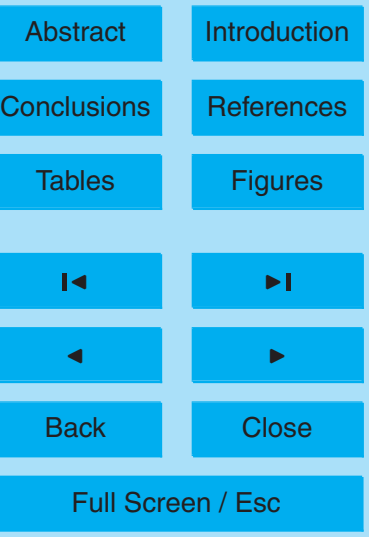

Printer-friendly Version

Interactive Discussion 


\section{ACPD}

10, 8553-8594, 2010

Table 3. Estimated uncertainty and impact of the parameters and processes which influences the modeled PN concentration at HCOE and VVHL. A large uncertainty and large impact of a process means that this process introduces a potentially large error in the model results.

\begin{tabular}{llll}
\hline Parameter/Process & Uncertainty & Impact HCOE & Impact VVHL \\
\hline Background concentration & Moderate & Large & Large \\
Dry dep. velocity & Large & Very small & Moderate \\
Coagulation & Small & Very small & Moderate \\
Cond./Evap. & Very large & Very small & Small \\
Mixing height & Large & Large & Large \\
Path of trajectory & Large & Large & Moderate \\
Time spent over the city & moderate & Large & Moderate \\
Vertical mixing & Large & Moderate & Small \\
Horizontal mixing & Large & Very small & Small \\
$\mathrm{NO}_{\mathrm{x}}$ emissions & Moderate & Large & Large \\
${\mathrm{PN} \mathrm{from} \mathrm{NO}_{\mathrm{x}} \text { ratio }}_{\mathrm{Spatial} \mathrm{variability} \mathrm{of} \mathrm{emissions}}$ & Moderate & Large & Large \\
& Moderate & Large & Large \\
\hline
\end{tabular}

Aerosol dynamics in the Copenhagen urban plume

F. Wang et al.

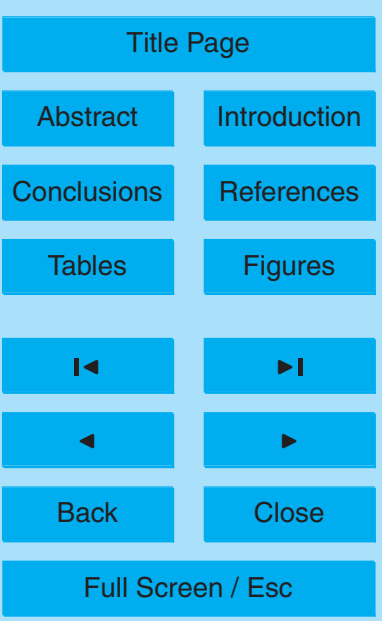

Printer-friendly Version

Interactive Discussion 


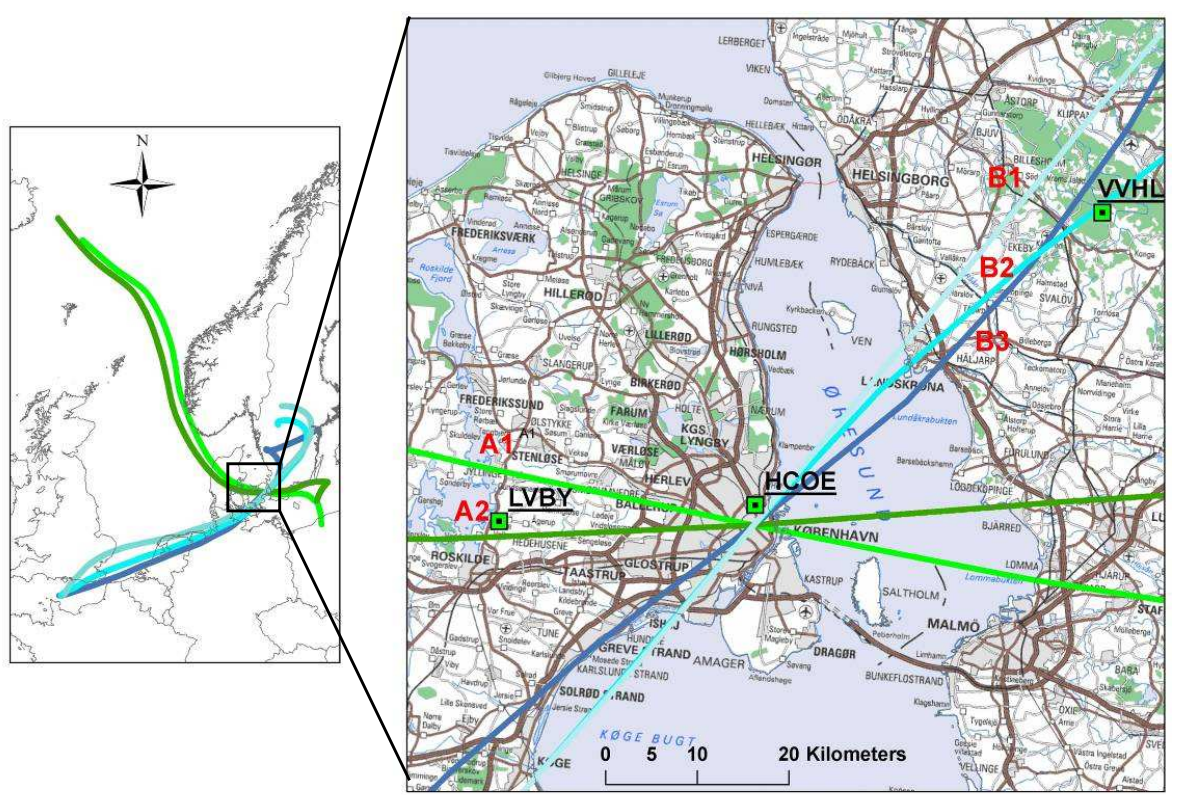

Fig. 1. The right panel shows a map of the Øresund region together with the positions of the monitoring stations Lille Valby (LVBY, near-city background), H. C. Ørsted Institute (HCOE, urban background) and Vavihill (VVHL, rural background). The right panel is an enlarged insert of left panel. Both panels also show the trajectories for the selected model simulations; group A simulations (west to east, 2 model cases, in green) and group B (south west to north east, 3 model cases, in blue) (Background map (C) www.kms.dk).
ACPD

10, 8553-8594, 2010

Aerosol dynamics in the Copenhagen urban plume

F. Wang et al.

Title Page

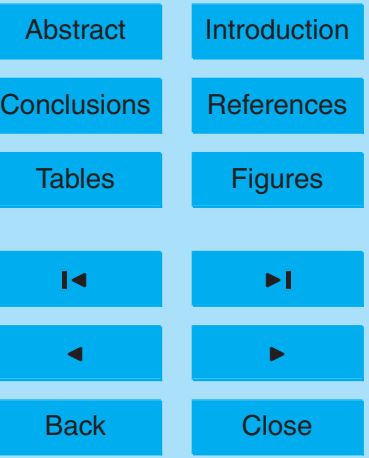

Full Screen / Esc

Printer-friendly Version

Interactive Discussion 


\section{ACPD}

$10,8553-8594,2010$

\section{Aerosol dynamics in} the Copenhagen urban plume
F. Wang et al.

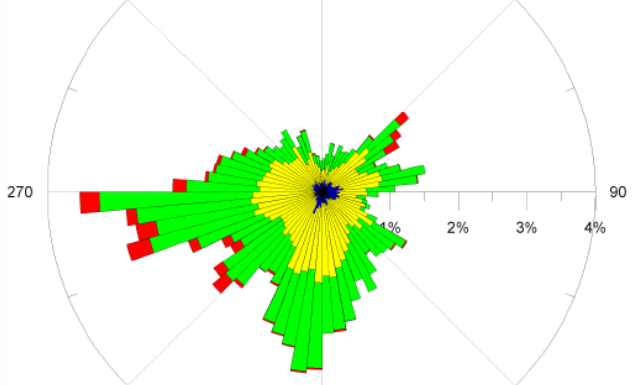

225

135

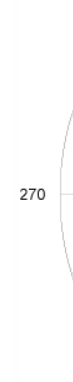

225
315
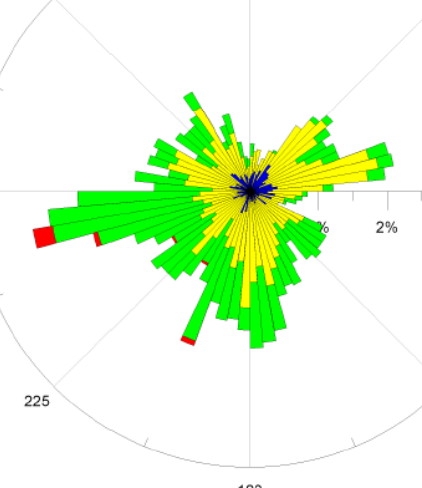

180

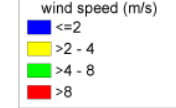

45

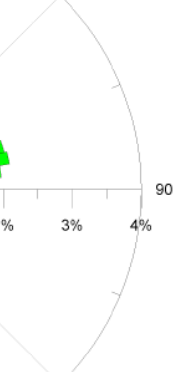

180

Fig. 2. The left panel shows the wind rose for the entire year of 2005 at the HCOE station, and the right panel shows the wind rose for the selected 6-week measurement period.

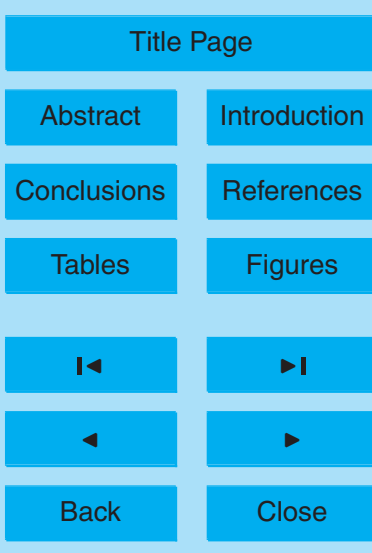

Full Screen / Esc

Printer-friendly Version

Interactive Discussion 


\section{ACPD}

$10,8553-8594,2010$
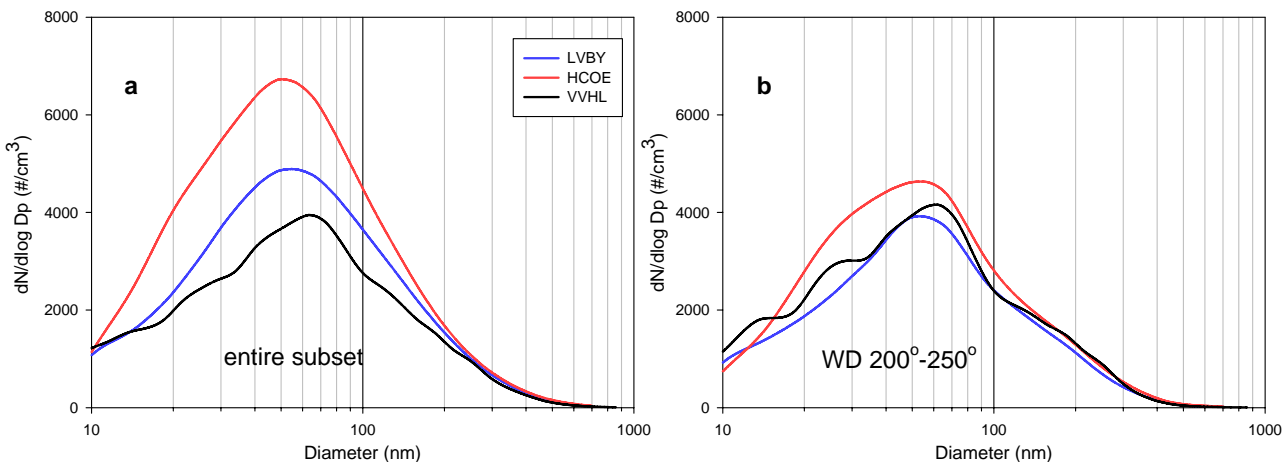

Fig. 3. Particle number size distributions at the three stations LVBY, HCOE and VVHL for (a) the entire 6-week dataset and for (b) the wind sector $200^{\circ}-250^{\circ}$ including 363 half-hour averages.

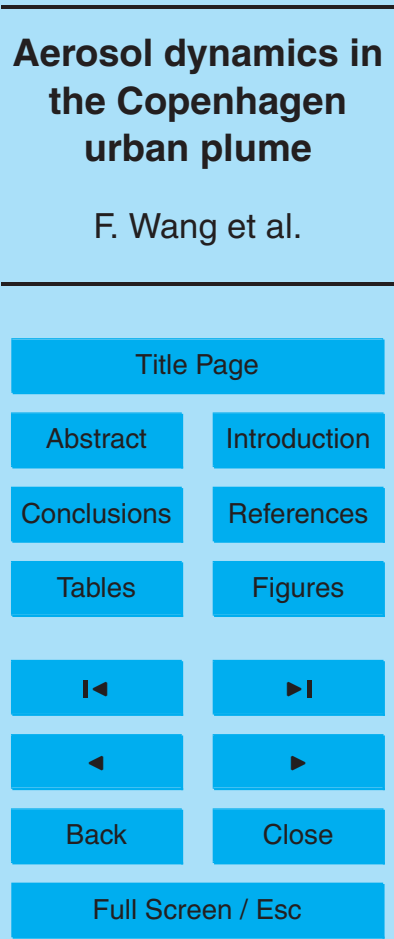

Printer-friendly Version

Interactive Discussion 


\section{ACPD}

$10,8553-8594,2010$

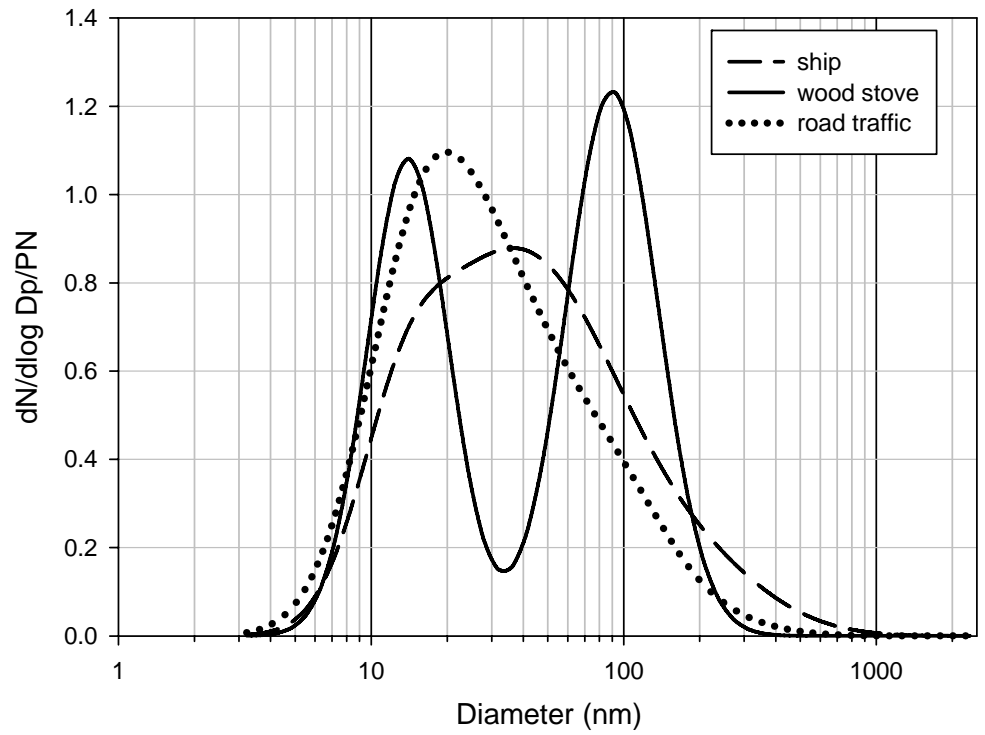

Fig. 4. Particle number size distribution of primary particle number emission profiles from road traffic (Wang et al., 2009), ship traffic (Petzold et al., 2008) and wood stoves (Wåhlin et al., 2010).

\section{Aerosol dynamics in} the Copenhagen urban plume

\section{F. Wang et al.}

Title Page

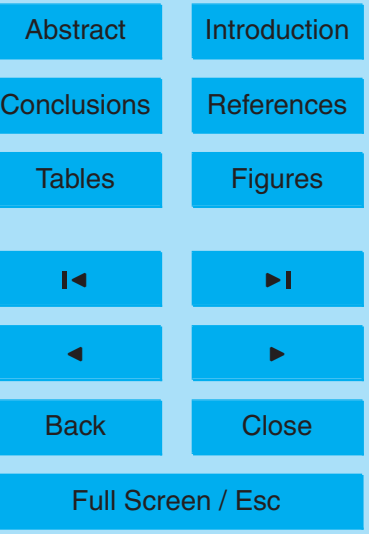

Printer-friendly Version

Interactive Discussion 

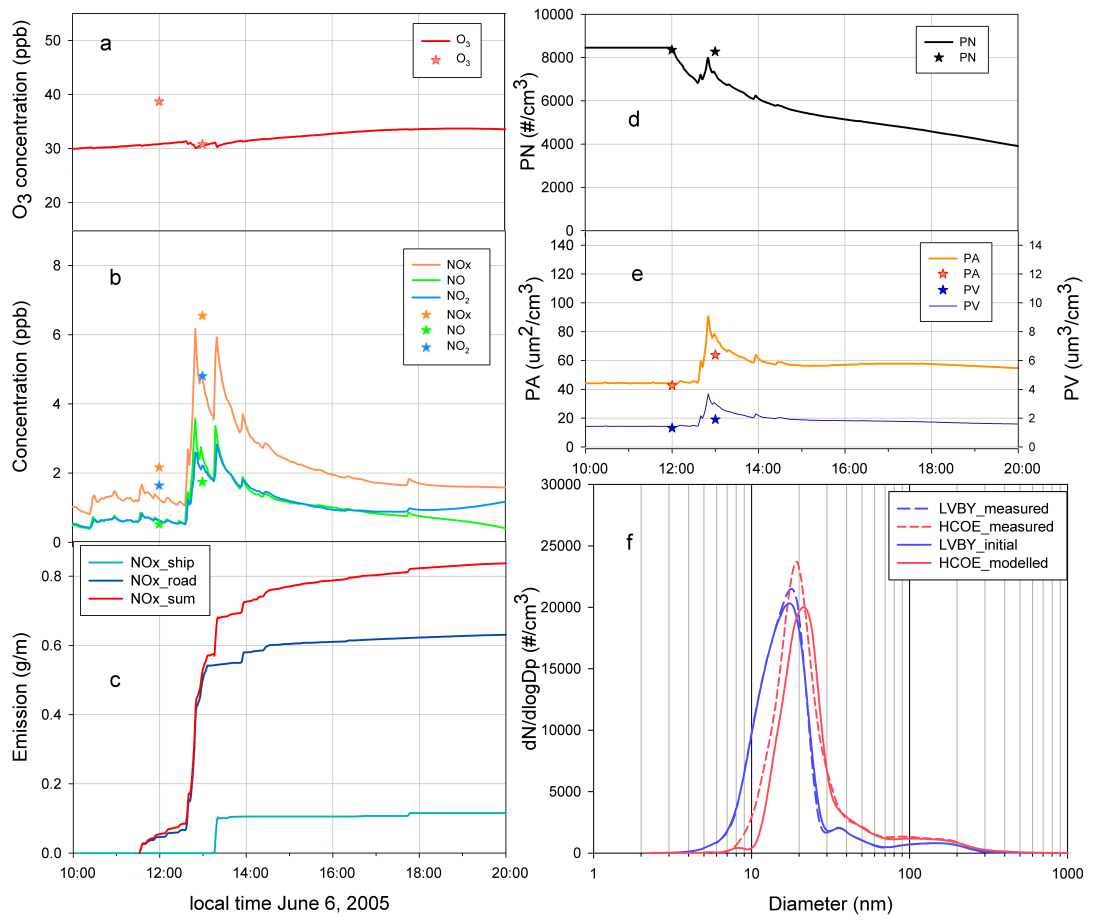

10, 8553-8594, 2010

Aerosol dynamics in the Copenhagen urban plume

F. Wang et al.

Title Page

Abstract

Introduction

Conclusions

References

Tables

Figures

14

Back

Close

Full Screen / Esc are shown as stars and modelled data are shown as solid lines in the following figures: (a) $\mathrm{O}_{3}$ concentration, (b) $\mathrm{NO}_{x}, \mathrm{NO}$ and $\mathrm{NO}_{2}$ concentration, (c) $\mathrm{NO}_{\mathrm{x}}$ emission increments from ship traffic, road traffic and sum of boths, (d) particle number (PN) concentration, (e) particle area (PA) concentration, left scale and particle volume (PV) concentration, right scale, (f) particle number size distribution (PNSD) measured and modeled at both LVBY and HCOE station.

Interactive Discussion 


\section{ACPD}

10, 8553-8594, 2010
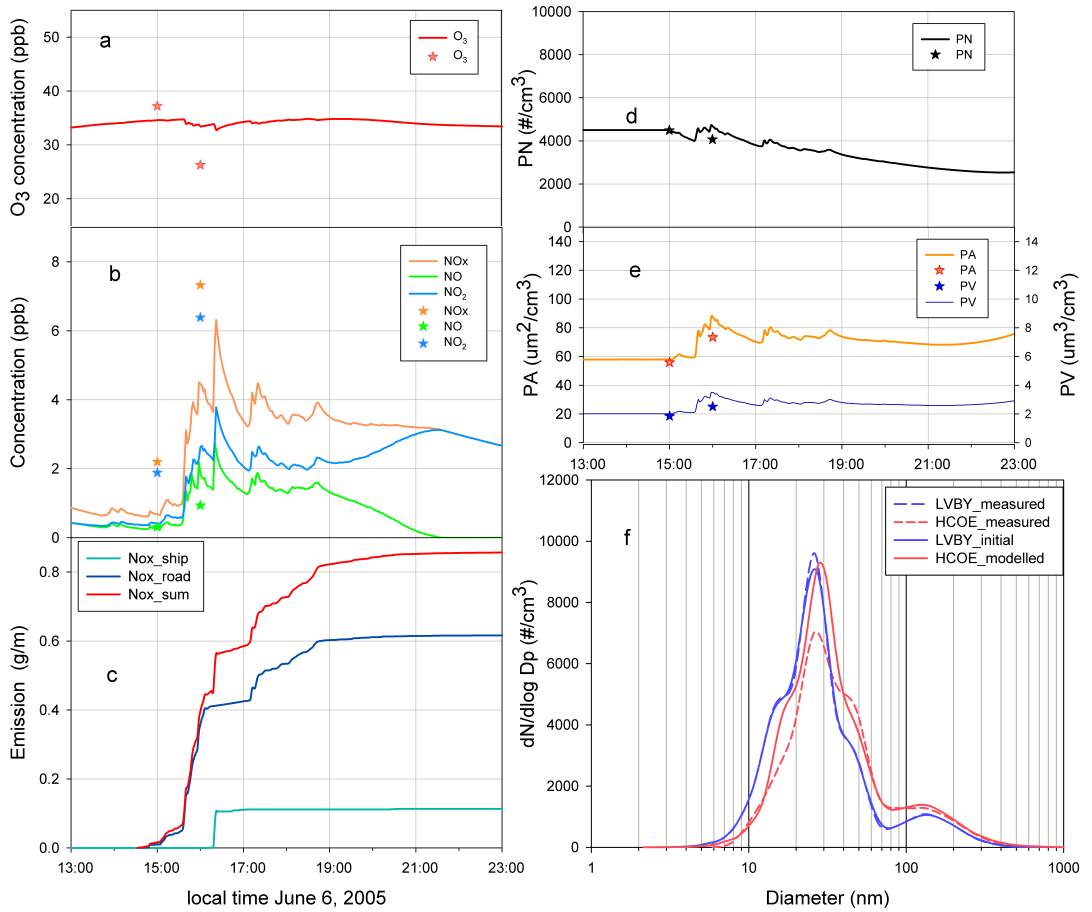

Aerosol dynamics in the Copenhagen urban plume

F. Wang et al.

Title Page

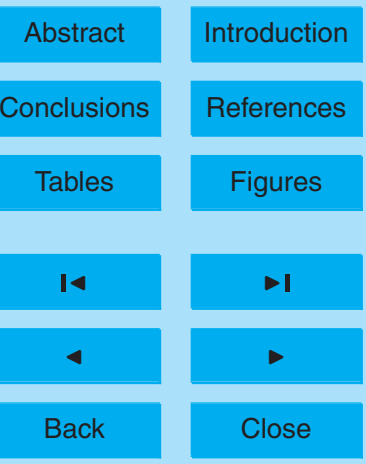

Full Screen / Esc

Fig. 6. As Fig. 5 here for Case A2.

Printer-friendly Version

Interactive Discussion 

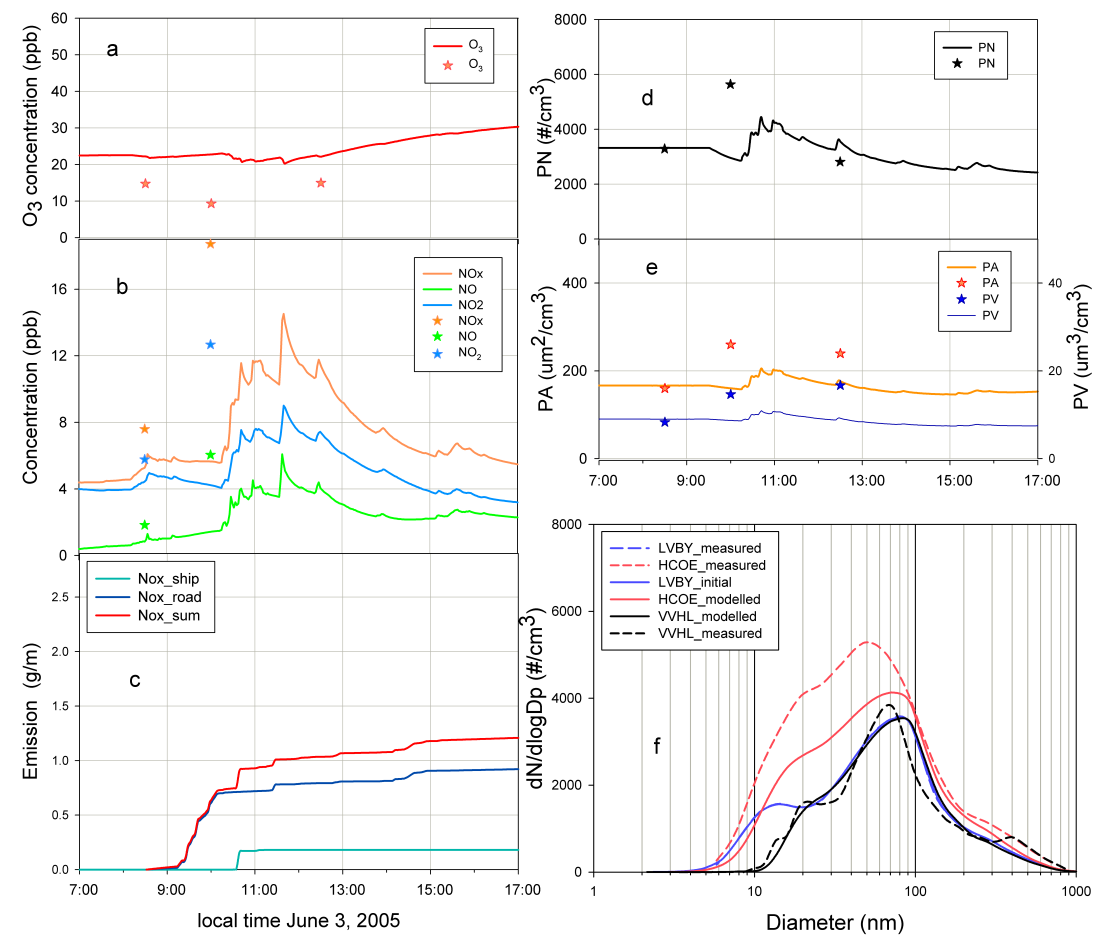

Fig. 7. Case $B 1$, air mass passing over the area of LVBY passing through $\mathrm{HCOE}$, and arriving the area of VVHL, measured data are shown as stars and modelled data are shown as solid lines in the following figures: (a) $\mathrm{O}_{3}$ concentration, (b) $\mathrm{NO}_{\mathrm{x}}, \mathrm{NO}$ and $\mathrm{NO}_{2}$ concentration, (c) $\mathrm{NO}_{\mathrm{x}}$ emission increment from ship traffic, road traffic and sum of both, (d) particle number (PN) concentration, (e) particle area (PA) concentration, left scale and particle volume (PV) concentration, right scale, (f) particle number size distribution (PNSD) measured and modelled at LVBY, HCOE and VVHL station.

\section{ACPD}

10, 8553-8594, 2010

Aerosol dynamics in the Copenhagen urban plume

F. Wang et al.

Title Page

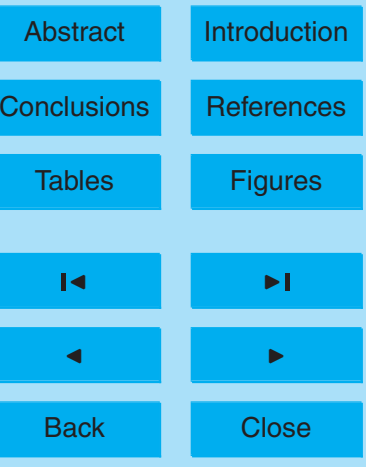

Full Screen / Esc

Printer-friendly Version

Interactive Discussion 


\section{ACPD}

10, 8553-8594, 2010
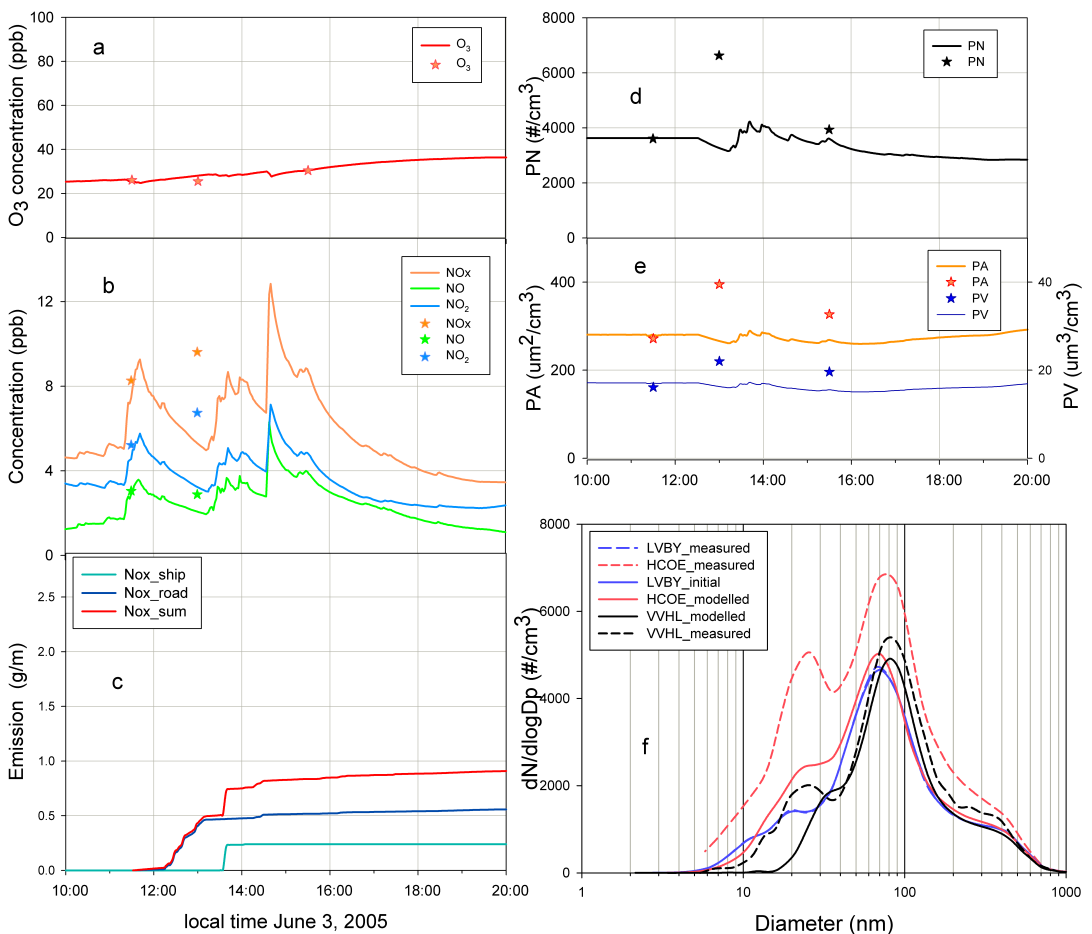

Aerosol dynamics in the Copenhagen urban plume
F. Wang et al.

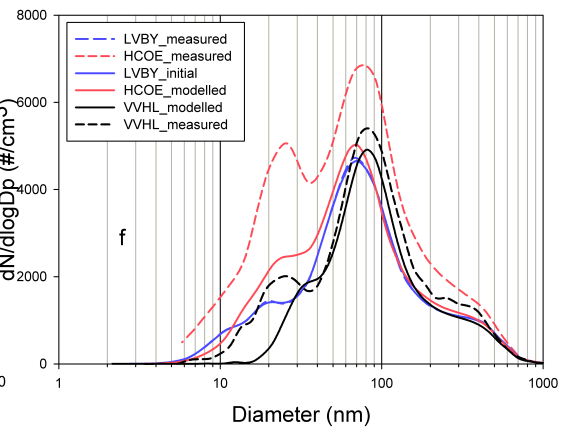

Title Page

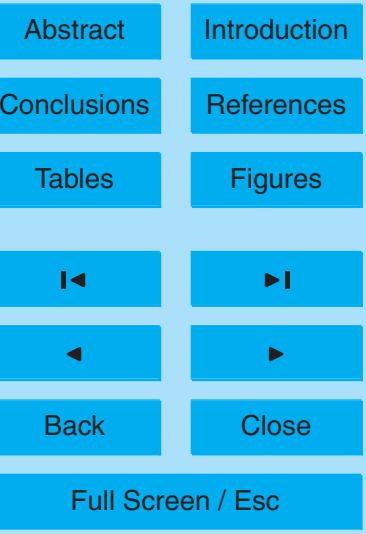

Fig. 8. As Fig. 7, here for case B2. 


\section{ACPD}

10, 8553-8594, 2010
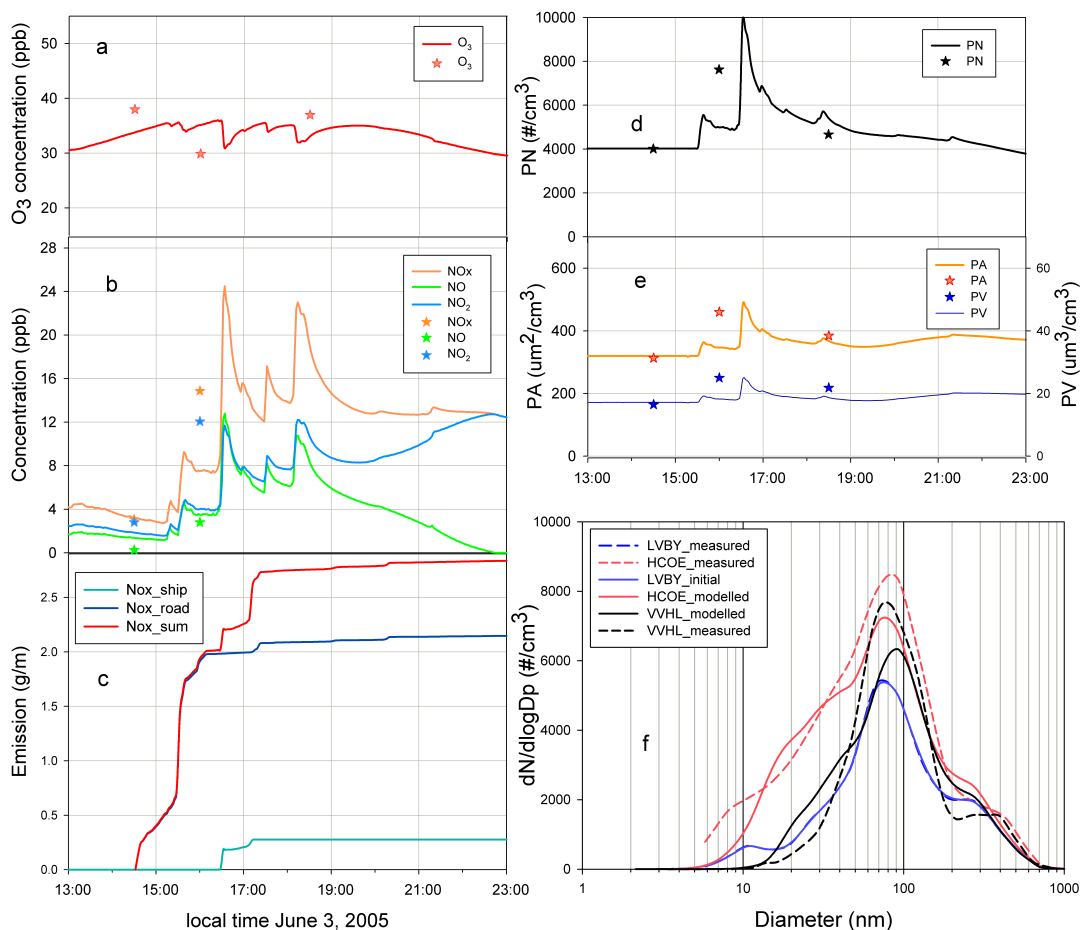

Aerosol dynamics in the Copenhagen urban plume
F. Wang et al.

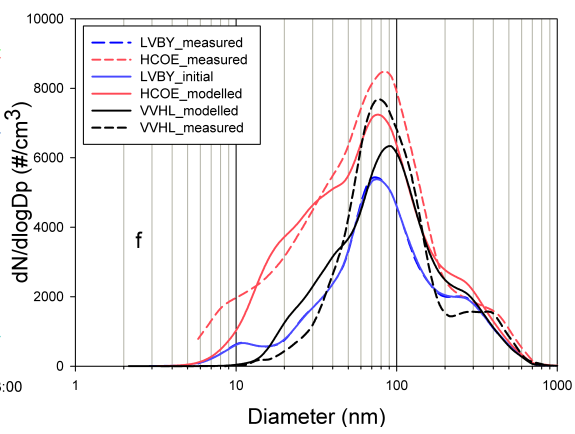

Title Page

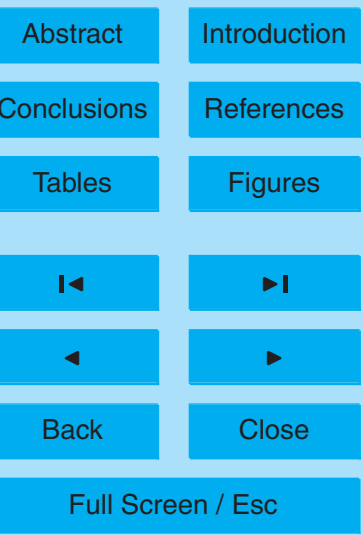

Fig. 9. As Fig. 7, here for case B3.

Printer-friendly Version

Interactive Discussion 


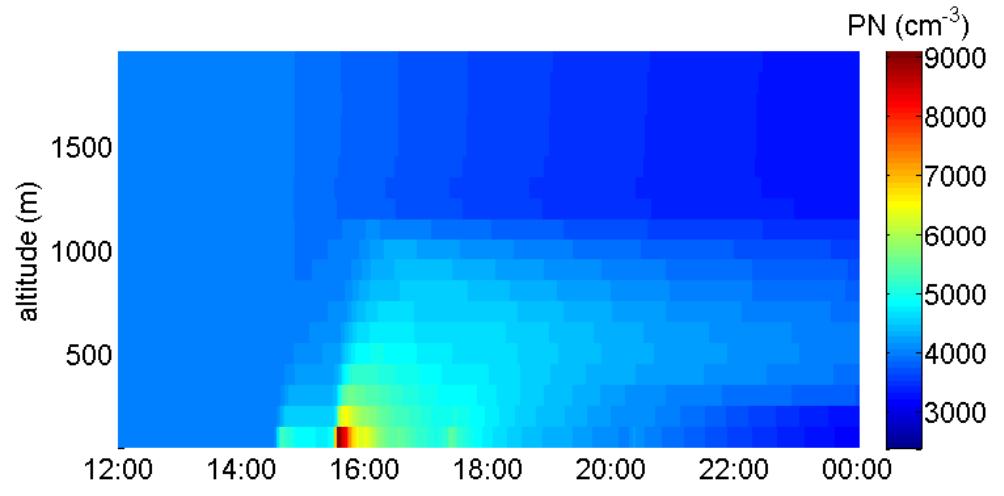

10, 8553-8594, 2010

Aerosol dynamics in the Copenhagen urban plume

F. Wang et al.
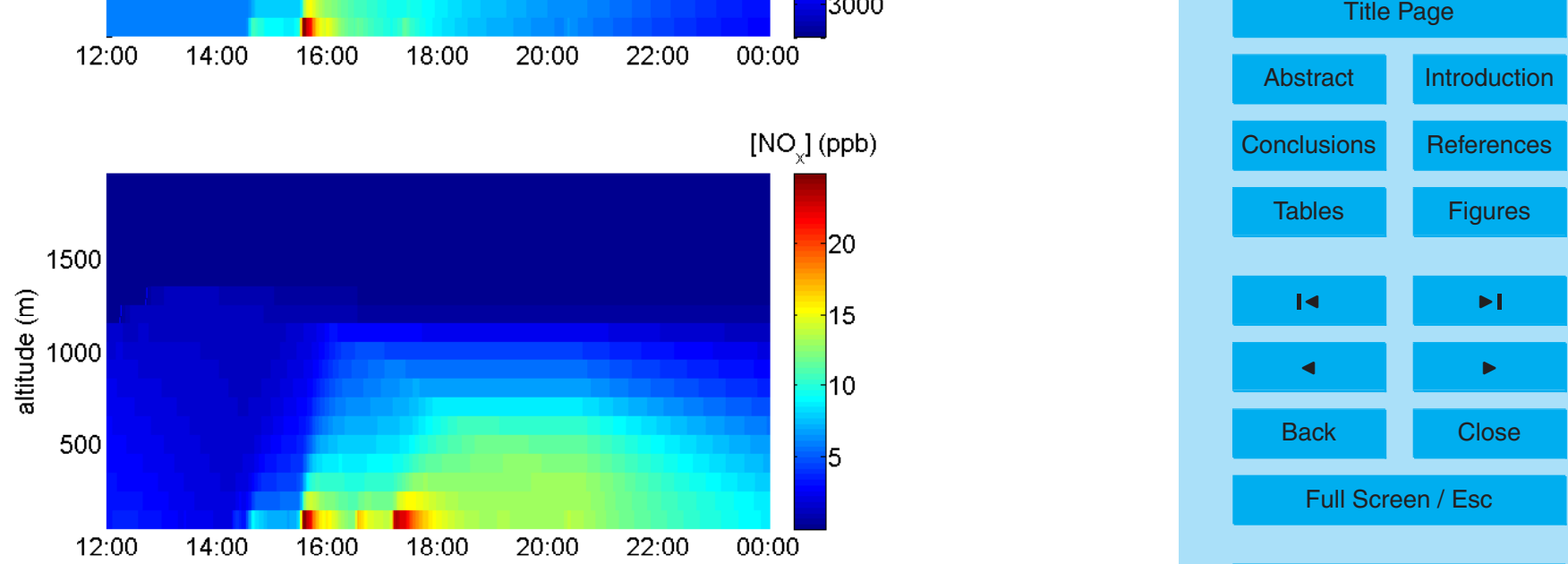

Fig. 10. Vertical profile of $\mathrm{NO}_{\mathrm{x}}$ and $\mathrm{PN}$ concentration for case B3.

Printer-friendly Version

Interactive Discussion 

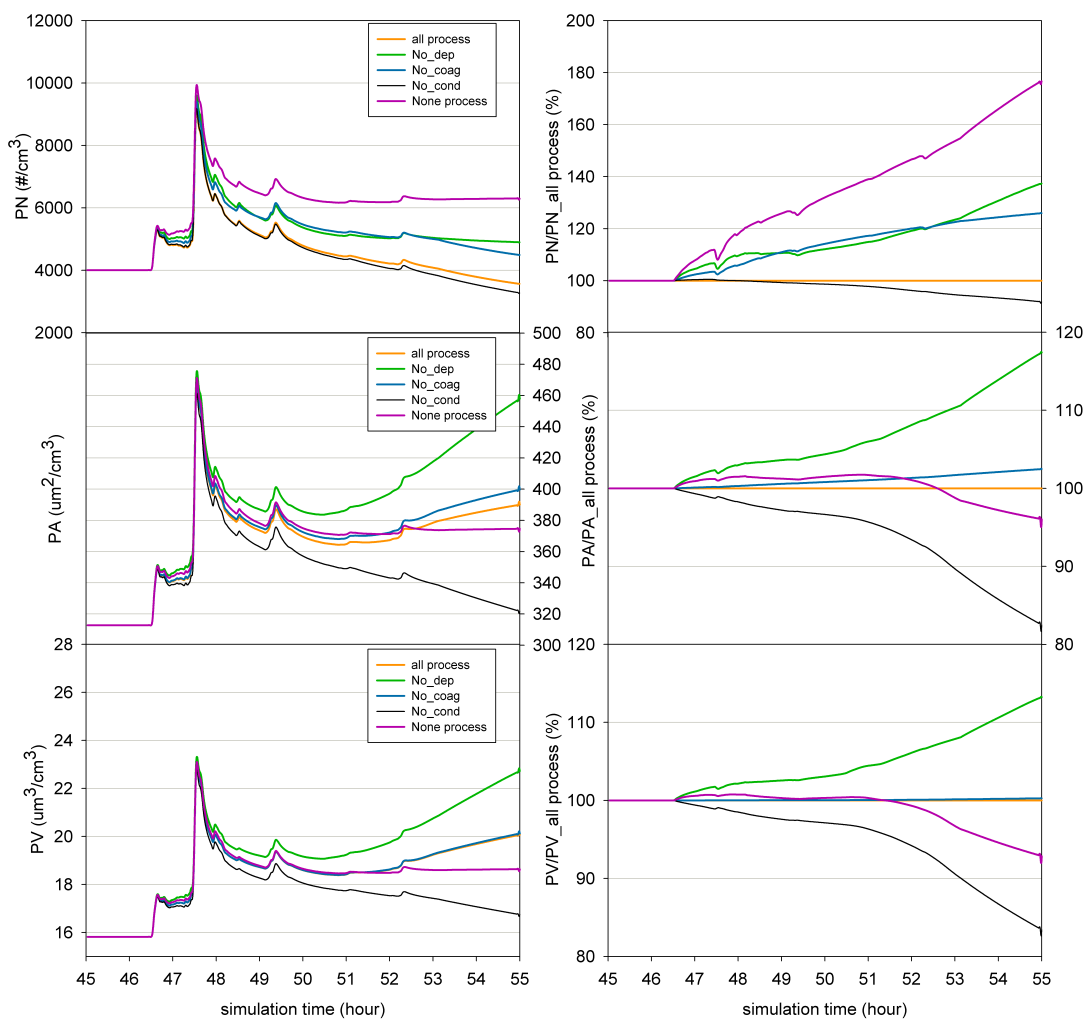

ACPD

10, 8553-8594, 2010

Aerosol dynamics in the Copenhagen urban plume

F. Wang et al.

Title Page

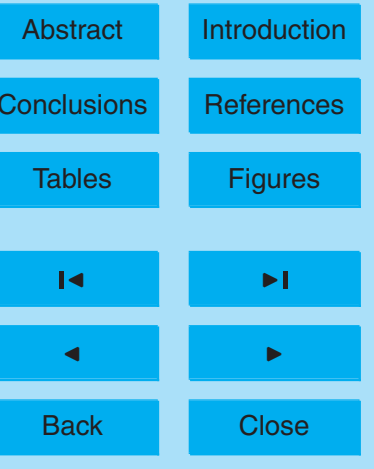

Fig. 11. $P N, P A$, and $P V$ calculated for case $B 3$ excluding individual aerosol dynamic processes (left), relative increase or decrease of these values in percent when individual aerosol dynamic

Full Screen / Esc processes were excluded (right). The different dynamic processes labeled in the legend are explained in Table 2. 


\section{ACPD}

10, 8553-8594, 2010
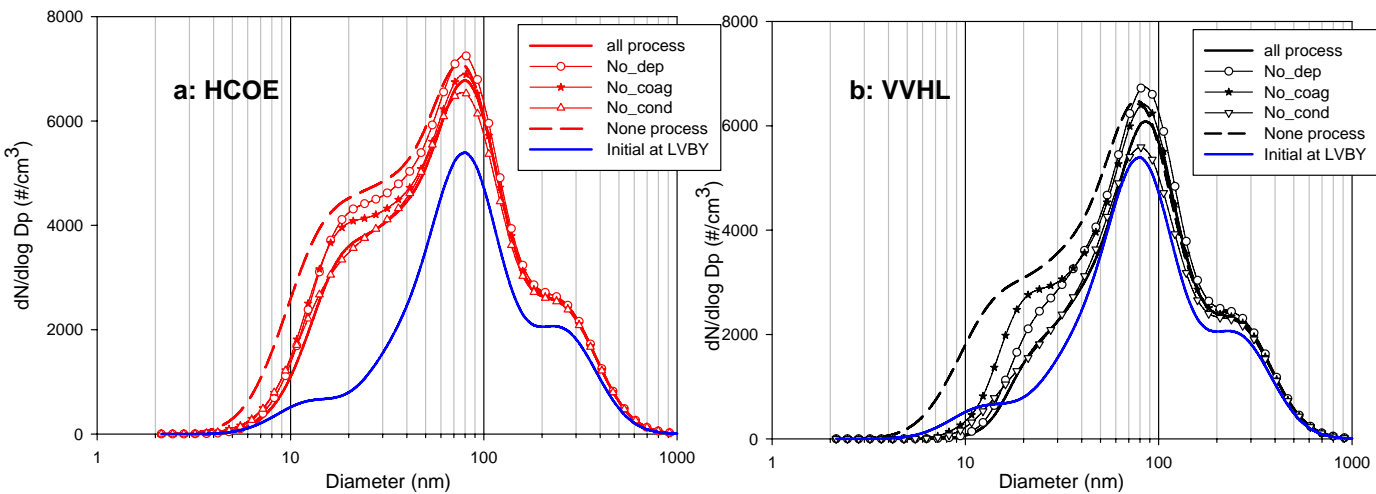

Fig. 12. Particle number size distribution at (a) HCOE (after about $1.5 \mathrm{~h}$ transport) and (b) VVHL (after about $4 \mathrm{~h}$ ) for case B3 simulating different aerosol dynamic processes excluded.

\section{Aerosol dynamics in} the Copenhagen urban plume

F. Wang et al.

Title Page

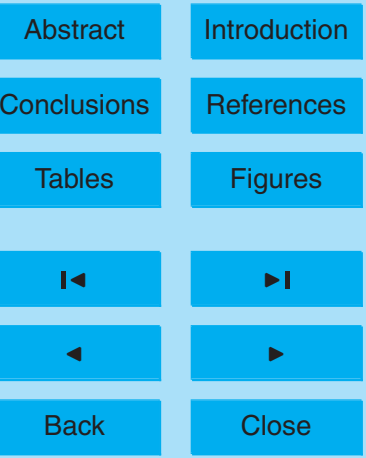

Full Screen / Esc

Printer-friendly Version

Interactive Discussion 